\title{
Land-use history impacts spatial patterns and composition of woody plant species across a 35-hectare temperate forest plot
}

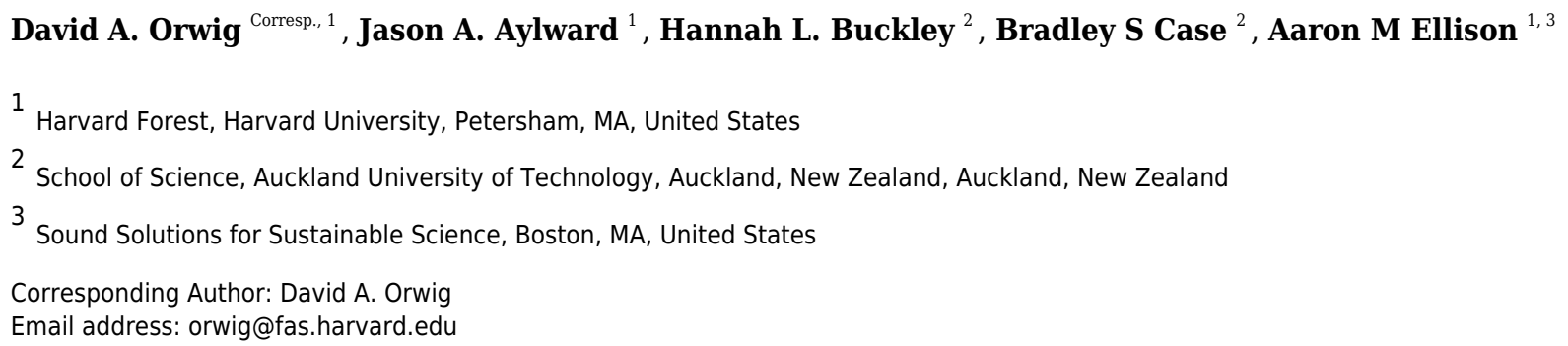

Land-use history is the template upon which contemporary plant and tree populations establish and interact with one another and exerts a legacy on the structure and dynamics of species assemblages and ecosystems. We use the first census (2010-2014) of a 35-ha forest-dynamics plot at the Harvard Forest in central Massachusetts to describe the composition and structure of the woody plants in this plot, assess their spatial associations within and among the dominant species using univariate and bivariate spatial pointpattern analysis and examine the interactions between land-use history and ecological processes. The plot includes 108,632 live stems $\geq 1 \mathrm{~cm}$ in diameter ( 2215 individuals/ha) and 7,595 standing dead stems $\geq 5 \mathrm{~cm}$ in diameter. Live tree basal area averaged 42.25 $\mathrm{m} 2 / \mathrm{ha}$, of which $84 \%$ was represented by Tsuga canadensis ( $14.0 \mathrm{~m} 2 /$ ha), Quercus rubra (northern red oak; $9.6 \mathrm{m2} / \mathrm{ha}$ ), Acer rubrum (7.2 $\mathrm{m} 2 / \mathrm{ha}$ ) and Pinus strobus (eastern white pine; $4.4 \mathrm{~m} 2 / \mathrm{ha}$ ). These same four species also comprised $78 \%$ of the live aboveground biomass, which averaged $245.2 \mathrm{Mg} / \mathrm{ha}$. Across all species and size classes, the forest contains a preponderance $(>80,000)$ of small stems $(<10-\mathrm{cm}$ dbh) that exhibit a reverse-J size distribution. Significant spatial clustering of abundant overstory species was observed at all spatial scales examined. Spatial distributions of $A$. rubrum and $Q$. rubra showed negative intraspecific correlations in diameters up to at least a 150-m spatial lag, likely indicative of crowding effects in dense forest patches following intensive past land use. Bivariate marked point-pattern analysis showed that $T$. canadensis and $Q$. rubra diameters were negatively associated with one another, indicating resource competition for light. Distribution and abundance of the common overstory species are predicted best by soil type, tree neighborhood effects, and two aspects of land-use history: when fields were abandoned in the late 19th century and the succeeding forest types recorded in 1908. In contrast, a history of intensive logging prior to 1950 and a damaging hurricane in 1938 
appear to have had little effect on the distribution and abundance of present-day tree species. Our findings suggest that current day composition and structure are still being influenced by anthropogenic disturbances that occurred over a century ago. 
1 Land-use history impacts spatial patterns and

2 composition of woody plant species across a 35-

3 hectare temperate forest plot

4

5

6

7

8

David A. Orwig ${ }^{1}$, Jason A. Aylward ${ }^{1}$, Hannah L. Buckley ${ }^{2}$, Bradley S. Case ${ }^{2}$, Aaron M. Ellison ${ }^{1,3}$

${ }^{1}$ Harvard Forest, Harvard University, Petersham, MA, USA

${ }^{2}$ School of Science, Auckland University of Technology, Auckland, New Zealand

${ }^{3}$ Sound Solutions for Sustainable Science, Boston, MA USA

email: aaron@ssforss.com

Corresponding Author:

David A. Orwig ${ }^{1}$

324 North Main Street, Petersham, MA, 01366, USA

Email address: orwig@fas.harvard.edu

\section{Abstract}

Land-use history is the template upon which contemporary plant and tree populations establish and interact with one another and exerts a legacy on the structure and dynamics of species assemblages and ecosystems. We use the first census (2010-2014) of a 35-ha forest-dynamics plot at the Harvard Forest in central Massachusetts to describe the composition and structure of the woody plants in this plot, assess their spatial associations within and among the dominant species using univariate and bivariate spatial point-pattern analysis and examine the interactions between land-use history and ecological processes. The plot includes 108,632 live stems $\geq 1 \mathrm{~cm}$ in diameter (2215 individuals/ha) and 7,595 standing dead stems $\geq 5 \mathrm{~cm}$ in diameter. Live tree basal area averaged $42.25 \mathrm{~m} 2 / \mathrm{ha}$, of which $84 \%$ was represented by Tsuga canadensis $(14.0 \mathrm{~m} 2 /$ ha), Quercus rubra (northern red oak; $9.6 \mathrm{~m} 2 /$ ha), Acer rubrum (7.2 $\mathrm{m} 2 /$ ha) and Pinus strobus (eastern white pine; $4.4 \mathrm{~m} 2 /$ ha). These same four species also comprised $78 \%$ of the live aboveground biomass, which averaged $245.2 \mathrm{Mg} / \mathrm{ha}$. Across all species and size classes, the forest contains a preponderance $(>80,000)$ of small stems $(<10-\mathrm{cm} \mathrm{DBH})$ that exhibit a reverse-J size distribution. Significant spatial clustering of abundant overstory species was observed at all spatial scales examined. Spatial distributions of A. rubrum and Q. rubra showed negative intraspecific correlations in diameters up to at least a $150-\mathrm{m}$ spatial lag, likely indicative of crowding effects in dense forest patches following intensive past land use. Bivariate marked point-pattern analysis showed that $T$. canadensis and Q. rubra diameters were negatively associated with one another, indicating resource competition for light. Distribution and abundance of the common overstory species are predicted best by soil type, tree neighborhood 
40

41

42

43

44

45

46

47

48

49

50

51

52

53

54

55

56

57

58

59

60

61

62

63

64

65

66

67

68

69

70

71

72

73

74

75

76

77

78

79

effects, and two aspects of land-use history: when fields were abandoned in the late 19th century and the succeeding forest types recorded in 1908. In contrast, a history of intensive logging prior to 1950 and a damaging hurricane in 1938 appear to have had little effect on the distribution and abundance of present-day tree species. Our findings suggest that current day composition and structure are still being influenced by anthropogenic disturbances that occurred over a century ago.

\section{Introduction}

In forested landscapes around the world, legacies of human activities have shaped the composition, size structure, and spatial patterns of trees, understory vegetation, and associated ecosystem processes (Birks et al. 1988, Turner et al. 1990, Russell 1997, Foster and Aber 2004, Ellison et al. 2014). The extent of the interactions between anthropogenic effects and abiotic factors such as climate, soils, and episodic disturbances in shaping vegetation patterns depends on the intensity of the effects and the spatial scale of analysis (Rackham 1986, Glitzenstein et al. 1990, Zimmerman et al. 1995). A complex interplay of succession, competition, disturbance, environment, and land use shape dynamics and patterns of forests at local-to-regional scales (Condit et al. 2000, Thompson et al. 2002, Chazdon 2003, Van Gemerden et al. 2003).

By further examining the spatial patterns of trees within a forest, ecologists can begin to uncover the underlying processes and mechanisms that led to those patterns (e.g., are species randomly distributed, aggregated, or dispersed in space and why? Wiegand et al. 2013). A growing number of studies have used point pattern analysis to examine the spatial structure of forests by using fully mapped plots, as each tree, or point, has a mapped location (Zhang et al. 2010, Wang et al. 2011, Lutz et al. 2013, Fibich et al. 2016, Nguyen et al. 2016). A variety of univariate and bivariate point pattern analysis methods and summary characteristics have been used to characterize the spatial patterning of trees (Wiegand and Moloney 2004, 2014). Since each method tells something different about the spatial structure of the data within a forest, it is more desirable to use multiple summary characteristics to better describe the patterns of tree species and among species associations (Illian et al. 2008, Weigand et al. 2013).

The forests of New England, USA have been shaped by a variety of natural and anthropogenic factors. As in other forests, the geology and climate of New England define the broad patterns of current forest composition (Foster et al. 1992, Hall et al. 2002), but the shifts in species abundance and distribution patterns that have occurred since Europeans colonized New England more than 400 years ago have resulted in a relatively homogenous assemblage of young, even-aged stands with fewer late-successional species (Thompson et al. 2013). In Massachusetts, modern vegetation exhibits only weak relationships to broad climatic gradients because of the overwhelming influence of past land use (Foster et al. 1998). An increasing emphasis in ecological studies is evaluating the relative importance of historic land-clearing, agriculture, intensive harvesting (Foster 1992, Thompson et al. 2002, Rhumtella et al. 2009, Hogan et al. 2016), and natural episodic storms (Foster and Boose 1992, Zimmerman et al. 1995) on current-day structure and species composition of forest stands (Motzkin et al. 1996, Motzkin 
80

81

82

83

84

85

86

87

88

89

90

91

92

93

94

95

96

97

98

99

100

101

102

103

104

105

106

107

108

109

110

111

112

113

114

115

116

117

118

119

et al. 1999, Bürgi et al. 2017). While evaluating which of these variables are most important in shaping current day structure and composition is challenging, the development and use of statistical approaches like recursive partitioning and conditional inference trees has aided the interpretation and prediction of these types of analyses (Hothorn et al. 2006).

Harvard Forest is an ideal location to investigate how spatial patterns and composition of woody plants are influenced by land-use history impacts. For more than a century, Harvard Forest (HF) researchers have investigated and recorded impacts of land-use on forests and how New England's forests are continuing to change as the regional climate changes, populations of large herbivores wax and wane, and nonnative insects and pathogens establish, irrupt, and kill tree species (Foster and Aber 2004).

Here, we describe the results of the first census of a fully mapped 35-ha forest-dynamics plot at the Harvard Forest and examine how its structure and composition relates to interactions between land-use history and ecological processes. We first describe the composition and structure of the woody plants in this plot and assess spatial associations within and among the dominant species using univariate and bivariate spatial point-pattern analysis. Second, we uncover the influence of historical land-use and natural disturbances on the current-day structure and composition of this forest plot. We pay particular attention to patterns of distribution and abundance of Tsuga canadensis (eastern hemlock) and its relationship to other species in the plot because previous work has shown it to be a foundation species in this forest (e.g., a species that defines ecosystems, controlling the biological diversity of associated species and modulating critical ecosystem processes; sensu (Ellison 2019)). Tsuga canadensis is currently threatened and declining throughout much of the HF plot and its range due to a nonnative insect, Adelges tsugae (hemlock woolly adelgid; HWA) and its decline and loss are likely to have profound impacts on forest structure and composition (Orwig et al. 2013, Foster 2014).

\section{Materials \& Methods}

\section{Site description}

The 35-ha $(500 \times 700 \mathrm{~m}) \mathrm{HF}$ forest-dynamics plot is part of a global network of Forest Global Earth Observatory (ForestGEO) plots established to monitor, understand, and predict forest dynamics and responses to global change (Anderson-Teixeira et al. 2015). The HF ForestGEO plot (southwest corner at $42.5386^{\circ} \mathrm{N}, 72.1798^{\circ} \mathrm{W}$ ) is located within the 380 -ha HF Prospect Hill tract in Petersham, Massachusetts, USA within the Worcester/Monadnock Plateau ecoregion of Transition Hardwoods-White Pine-Hemlock forests (Westveld 1956) (Fig. 1). Elevations in the plot range from 340.2 to $367.8 \mathrm{~m}$ a.s.l. Soils include Gloucester stony loam, Acton stony loam and Whitman very stony silt loams, all of which are gravelly and fine sandy loam soils that developed in glacial tills overlying gneiss and schist bedrock (Simmons 1941). The north-central portion of the plot contains a 3-ha peat swamp with muck soils that has been colonized at intervals by Castor canadensis (beaver). Average (1964-2019) annual temperature 
120

121

122

123

124

125

126

127

128

129

130

131

132

133

134

135

136

137

138

139

140

141

142

143

144

145

146

147

148

149

150

151

152

153

154

155

156

157

158

at the site is $7.9^{\circ} \mathrm{C}$ and the annual precipitation of $1090 \mathrm{~mm}$ is distributed evenly throughout the year (Boose and Gould 2019).

\section{Land-use history}

We examined the influence of past land-use history (derived from forest stand descriptions of dates of field abandonment, areas used as woodlot, pasture, or cultivation; presence of distinct plow horizon; silviculture treatments; and salvage operations), historical events (e.g., insect outbreaks, storms and associated degree of forest damage (Rowlands 1941) ), and biophysical attributes (roads, soil type, slope, aspect, elevation, and distance to streams) on current forest composition and species distribution within the plot by using data from the document archives at HF (http://harvardforest.fas.harvard.edu/document-archive). Original maps of activity were manually transcribed to standardized base maps and then scanned and digitized as shapefiles in ArcView GIS 3.2. The shapefiles were then transformed to Massachusetts State Plane Meters (NAD83 projection) in ArcGIS to align better with aerial photographs and linear features (trails, stonewalls, etc.) downloaded from MassGIS (Hall 2005) and used in spatial analyses (see below).

Pollen evidence suggests that prior to European settlement, Prospect Hill was a mixture of old-growth northern hardwoods, T. canadensis, and Pinus strobus (eastern white pine). Following European arrival, the site then experienced complex ownership and intensive land-use over the next few centuries, both of which are largely representative of the New England region (Ellison et al. 2014). Forest clearing began in 1750 and reached a maximum in the 1840 s, by which time close to $80 \%$ of the original forests had been cleared for agriculture (Fisher 1933, Raup and Carlson 1941). Field abandonment began in 1850 and continued through 1905 in the southern half of the plot (Fig. 2a). Reforestation of those fields continued through the 20th century (Foster 1992). The western, northern, and northeastern areas of the plot remained permanently wooded, but experienced various types of selective cutting in the 1790s and 1870s (Foster 1992). The first maps characterizing forest types of individual stands were completed in 1908 and classified the permanent woodlots in the western third of the plot as being comprised of hardwoods, white pine-hardwoods, hemlock, and red maple (Fig 2b). Many Castanea dentata (American chestnut) died in 1912-1914 from infection by Endothia parasitica (chestnut blight) (McLachlan et al. 2000) and forests were damaged by natural disturbances including an ice storm in 1921 and one of the most damaging hurricanes to hit New England in 1938. The hurricane and subsequent salvage logging resulted in the loss of as much as $70 \%$ of the standing timber on HF properties (Foster and Boose 1992).

The central sections of the plot, containing mostly stony loam soils and no visible signs of a plow layer, were unimproved pastures abandoned in the mid-19th century (Motzkin et al. 1999) (Fig 2c). These areas reforested and were classified as cordwood (poor hardwood) in 1908 (Fig 2b), except for an area classified as open, which is the beaver swamp. Much of the cordwood section was subsequently clear-cut in the 1920s and then thinned or salvaged in the late 1940s following the 1938 hurricane. Pinus resinosa (red pine) and Picea abies (Norway 
159

160

161

162

163

164

165

166

167

168

169

170

171

172

173

174

175

176

177

178

179

180

181

182

183

184

185

186

187

188

189

190

191

192

193

194

195

196

197

198

spruce) plantations were established in portions of these abandoned pastures in the mid-1920s and early 1930s. The southcentral area of the plot contained areas of improved pasture and cultivation and was classified as containing white pine in 1908. This area was clear-cut in the 1920 s and a portion of it was clear-cut again in 1980, resulting in many small diameter, multistemmed trees. Additional biotic changes that impacted the plot included the exotic Lymantria dispar (gypsy moth), which lead to widespread defoliation of hardwoods during 1944-45 and 1981; Cryptococcus fagisuga (beech scale insect) combined with Neonectria fungal spp. (beechbark disease), which has led to the decline and death of larger Fagus grandifolia (American beech); and Adelges tsugae, which was first observed in the plot in 2008 and then rapidly spread throughout the plot, subsequently killing hundreds of $T$. canadensis stems and threatening the rest.

Plot establishment and woody stem census

During March 2010, professional surveyors delineated the plot boundaries, established a continuous grid of $20 \times 20-\mathrm{m}$ quadrats, and measured the elevation at each post using a Sokkia SET600 Total Station (Olathe, Kansas, USA). During the summers of 2010 and 2011, all woody stems $\geq 1 \mathrm{~cm}$ in diameter at breast height ( $\mathrm{DBH} ; 1.3 \mathrm{~m}$ above the ground level) were uniquely tagged, identified (nomenclature follows), and measured to the nearest $0.1 \mathrm{~cm} \mathrm{DBH}$ (Condit 1998). All dead stems $\geq 5 \mathrm{~cm}$ diameter that were standing and $>45$ degrees from horizontal also were tagged, identified, and measured. The swamp located in the center of the plot was sampled when the ground was frozen during the winter months of 2012-2014. Each tagged stem was mapped within one of four $10 \times 10 \mathrm{~m}$ subquadrats within each quadrat on a scale-drawn map data sheet. Each map was then scanned and individual stems were digitized using the Image $\mathrm{J}$ processing program (Rashband 2012), and converted to local $(x, y)$ coordinates within a quadrat using R (v.3.6.1) (R Core Team 2013) and the CTFS R package (Condit 2014).

\section{Forest species composition and stand structure}

Estimates of stem densities were derived from total counts in which multi-stemmed individuals were considered as a single stem, whereas estimates of basal area and biomass were derived from the sum of all stems $\geq 1 \mathrm{~cm} \mathrm{DBH}$ (Gilbert et al. 2010). Biomass of living woody stems was estimated from DBH using allometric equations (Table S1).

\section{Spatial analysis}

We assessed the spatial patterns of all stems of the seven most abundant overstory tree species across the entire plot using the pair-correlation function $(g(r)$; (Wiegand and Moloney 2014) ), for which the value of the function represents the degree of clustering $(g(r)>1)$ or overdispersion $(g(r)<1)$ at a given spatial lag (distance between neighboring trees). We compared the observed pair-correlation statistic to that expected if trees were distributed randomly $(g(r)=1)$ within the plot using 199 Monte Carlo CSR (complete spatial randomness) simulations of the tree map for each species. 
199

200

201

202

203

204

205

206

207

208

209

210

211

212

213

214

215

216

217

218

219

220

221

222

223

224

225

226

227

228

229

230

231

232

233

234

235

236

237

238

To test for the effects of intraspecific competition we used the univariate markcorrelation function ( $\mathrm{kmm}(\mathrm{r})$; (Wiegand and Moloney 2004, Wiegand and Moloney 2014)) to test whether the size (DBH) of each of the seven most abundant tree species depended on its proximity to neighbors of its own species. The value of $k m m(r)$ represents the relative sizes of trees at a given spatial lag and indicates if trees are larger or smaller than expected at a given spatial lag. We compared the observed univariate mark-correlation function statistic to that expected if the sizes of trees were randomly assigned across individuals using 199 Monte Carlo simulations for each species, i.e., the spatial pattern of the trees remained the same, but their sizes were shuffled (Jacquemyn et al. 2010). Spatial analyses were not conducted on shrub species as many only occurred in the central swamp area.

Prior work has shown that the shade-tolerant T. canadensis is an important foundation tree species, creating and strongly controlling the microenvironment, understory vegetation, and ecosystem dynamics (Ellison et al. 2005, Orwig et al. 2013). Thus, we assessed the potential influence of $T$. canadensis on the sizes of each of the other most common tree species in the plot using a bivariate marked point pattern analysis (Schlather's version of Moran's I markcorrelation function (Im Im2(r); (Wiegand and Moloney 2014). This statistic determines if tree sizes are spatially correlated: individuals are smaller or larger than expected at various distances from a neighbor. We compared the observed $\operatorname{Im} \operatorname{lm} 2(r)$ to that expected if the sizes of trees were randomly assigned across individuals using 199 Monte Carlo simulations for each species (Jacquemyn et al. 2010). All spatial pattern analyses were performed using the 2018 version of the software Programita (Wiegand and Moloney 2004, 2014).

GIS overlays of past land use, historical events, and biophysical attributes were used as covariates in a conditional inference regression-tree model to predict diameter and abundance of the most common overstory species in the plot (Table 1). Species-specific abundances or sizes were predicted for each of the seven most abundant overstory species conditional on their observed locations. A mean relative abundance (stems/ha) associated with each tree location was calculated using raster-based tools within the GIS. First, a moving $3 \times 3$ cell moving focal window analysis was used to generate a surface of mean tree abundances across the plot at a 20$\mathrm{m}$ cell resolution. Subsequently, to associate a mean relative abundance value with each tree, this generated surface was sampled in the GIS at the location of each tree. Using the 'cforest' function in the R package 'party' (Version 1.3-5) (Hothorn et al. 2013) the outcomes of 500 conditional inference tree models (Hothorn et al. 2006) were compiled and the relative importance of explanatory variables were ranked across all models. The conditional inference algorithm is based on a random forest machine-learning algorithm (Breiman 2001) used in many ecological modeling contexts (e.g., Fox et al. 2017, Mi et al. 2017, Mohapatra et al. 2019, Shearman et al. 2019). The conditional inference method improves on the variable ranking methodology by applying a permutation importance algorithm that corrects for variable selection bias resulting from a mix of categorical and continuous explanatory variables that are correlated to varying degrees or that have complex interactions (Strobl et al. 2007). Variable importance scores are calculated by determining the marginal loss of prediction accuracy from any given 
239

240

241

242

243

244

245

246

247

248

249

250

251

252

253

254

255

256

257

258

259

260

261

262

263

264

265

266

267

268

269

270

271

272

273

274

275

276

model iteration after removing each explanatory variable. Overall variable importance is determined by averaging the variable-wise decrease in accuracy scores over all 500 model iterations to rank the overall importance of each variable across all models.

Data availability

Data associated with this study are publicly available from the HF data archive (Orwig et al. 2015: HF253. http://harvardforest.fas.harvard.edu/data-archive).

\section{Results}

Composition and stand structure

Within the 35-ha HF ForestGEO plot, we identified 108,632 live stems $\geq 1 \mathrm{~cm} \mathrm{DBH,}$ representing 77,536 individuals $\left(2215 \mathrm{ha}^{-1}\right)$ of 51 woody species in 17 families (Table S2).

Common families were Betulaceae, Rosaceae, and Pinaceae (six species each), and Fagaceae and Adoxaceae (five species each). Four tree species (T. canadensis, Acer rubrum [red maple], $Q$. rubra [northern red oak], and P. strobus) and one shrub, Ilex verticillata (winterberry), accounted for $63 \%$ of all stems (Table 2). Live tree basal area averaged $42.25 \mathrm{~m}^{2} \mathrm{ha}^{-1}$ and average live aboveground biomass was $245.2 \mathrm{Mg} \mathrm{ha}^{-1}$. Eighty-four percent of the basal area and $78 \%$ of the biomass was represented by $T$. canadensis $\left(14.0 \mathrm{~m}^{2} \mathrm{ha}^{-1} ; 61.1 \mathrm{Mg} \mathrm{ha}^{-1}\right)$, Q rubra $(9.6$ $\left.\mathrm{m}^{2} \mathrm{ha}^{-1} ; 75.1 \mathrm{Mg} \mathrm{ha}^{-1}\right)$, A. rubrum $\left(7.2 \mathrm{~m}^{2} \mathrm{ha}^{-1} ; 33.8 \mathrm{Mg} \mathrm{ha}^{-1}\right)$ and P. strobus $\left(4.4 \mathrm{~m}^{2} \mathrm{ha}^{-1} ; 20.7\right.$ $\left.\mathrm{Mg} \mathrm{ha}^{-1}\right)$. The live tree diameter distributions of $T$. canadensis and $F$. grandifolia were strongly right-skewed (reverse-J shaped), whereas those of A. rubrum, Q. rubra, P. strobus, Betula lenta (black birch), and B. alleghaniensis (yellow birch) were less right-skewed (Fig. 3).

In contrast, $73 \%$ of tagged stems and $69 \%$ of live individuals within the plot were $<10$ cm DBH (Fig. 4). These same stems comprised only 5\% of the total live plot basal area and 3\% of the total live plot biomass (Table 2). Shrub species made up many of these stems with reverse-J size distributions and included I. verticillata, Vaccinium corymbosum (highbush blueberry), and Kalmia latifolia (mountain laurel). Nonnative species in the plot included 1687 stems of Picea abies (Norway spruce) and Pinus resinosa (red pine) that remained from early $20^{\text {th }}$-century conifer plantings and three stems of Frangula alnus (glossy false buckthorn). Ten species had only one or two stems within the plot (Table 2). Finally, there were 7595 dead stems $\geq 5 \mathrm{~cm} \mathrm{DBH}$ within the plot, $>50 \%$ of which were $T$. canadensis, P. strobus, or A. rubrum. Dead tree basal area was $4.18 \mathrm{~m}^{2} \mathrm{ha}^{-1}$ and dead aboveground biomass was $17.53 \mathrm{Mg} \mathrm{ha}^{-1}$.

\section{Spatial structure related to past land-use impacts}

The spatial distributions of the seven most common species varied across the plot (Fig. 5). Pinus strobus was common throughout the plot. Tsuga canadensis was most abundant in the western, northern, and eastern portions of the plot, whereas Q. rubra and A. rubrum dominated

Peer] reviewing PDF | (2021:08:64305:1:1:NEW 8 Nov 2021) 
277 the central and southern areas. Both Betula species were most abundant in the central and eastern

278

279

280

281

282

283

284

285

286

287

288

289

290

291

292

293

294

295

296

297

298

299

300

301

302

303

304

305

306

307

308

309

310

311

312

313

314

315

316

sections, and $F$. grandifolia was most common in the southeastern section.

Shrubs were also often spatially aggregated with respect to hydrology and topography. Ilex verticillata $V$. corymbosum, Viburnum nudum (withe-rod), and Lyonia ligustrina (maleberry) dominated the poorly drained beaver swamp (Fig. 6). Hamamelis virginiana (witch-hazel) was found in a narrow elevational band (342-346 m) surrounding the swamp and a dense patch of $K$. latifolia was located in the northwest corner of the plot.

The seven most abundant canopy tree species were significantly clustered in the plot at all spatial lags up to $50 \mathrm{~m}$ relative to a CSR null expectation (Fig. 7). The effect of intraspecific competition also was apparent for these seven species as smaller than expected diameters were observed when nearby individuals of the same species. For example, spatial distributions of $A$. rubrum, $Q$. rubra, and $F$. grandifolia showed negative intraspecific correlations in diameters up to at least a $150-\mathrm{m}$ spatial lag, whereas the other species had intraspecific negative correlations at $\leq 50 \mathrm{~m}$ spatial lags (Fig. 8). Tsuga canadensis, B. alleghaniensis, and P. strobus had positive spatial correlations (larger diameters than expected among DBHs at spatial lags $>150 \mathrm{~m}$. Interspecific correlations in diameters between species suggest that the impact of $T$. canadensis on $Q$. rubra was negative at intermediate spatial lags $(25-75 \mathrm{~m})$ but positive between $T$. canadensis and the other five species at most spatial scales up to $150 \mathrm{~m}$ (Fig. 9).

The abundances and sizes of the most common overstory species were predicted best by a variety of historical factors and competitive interactions. Conditional inference random-forest modeling revealed that the abundances of T. canadensis, $P$. strobus, $Q$. rubra, A. rubrum and F. grandifolia were strongly associated with neighborhood effects (size of neighboring trees within $10 \mathrm{~m}$; Fig. 10). The date of field abandonment was a strong predictor of $Q$. rubra, P. strobus, and $B$. lenta abundance, whereas the forest type in 1908 was the best predictor of $B$. alleghaniensis and $A$. rubrum abundance. Betula species also were strongly associated with Simmons soil type. Overstory species diameters were best predicted by neighborhood effects for $T$. canadensis, $B$. lenta, and F. grandifolia; date of field abandonment for P. strobus and B. alleghaniensis; and the 1947 stand type for Q. rubra and A. rubrum (Fig. 11). The predictive power of the conditional inference forest model regressions was much higher $\left(R^{2}=0.79-0.95\right)$ for species abundance in the plot compared to species size $\left(R^{2}=0.11-0.53\right)$.

\section{Discussion}

We censused all woody stems $\geq 1 \mathrm{~cm}$ DBH within a 35 -ha forest-dynamics plot in northcentral Massachusetts to examine the spatial patterns of trees and shrubs at a scale rarely attempted in temperate forests. We have shown that broad patterns in land use and historical disturbance that occurred up to a century ago remain dominant controls on present-day spatial distribution and structure of overstory species. Tree species were significantly clumped within the plot and T. canadensis affected the distribution of other dominant canopy species in different ways. Topography and hydrology also affected the distribution and abundance of understory stems. Detailed abundance and species distribution data provided in this study will provide

PeerJ reviewing PDF | (2021:08:64305:1:1:NEW 8 Nov 2021) 
317 invaluable information on forest dynamics in the future as the currently most abundant species-

318 Tsuga canadensis - is declining because of a non-native insect (Orwig et al. 2018).

319

320

Forest structure is contingent on past land use

321

The forest canopy within the HF ForestGEO plot, dominated by T. canadensis, Q. rubra,

322

323

324

325

326

327

328

329

330

331

332

333

334

335

336

337

338

339

340

341

342

343

344

345

346

347

348

349

350

351

352

353

354

355

A. rubrum, and P. strobus, is representative of many central New England forests. Like other temperate ForestGEO plots, a relatively small number of species dominated the HF plot (13 species were represented by over 1000 stems). However, this number was higher than the 5-10 species that reached this abundance in other temperate ForestGEO plots (Wang et al. 2010, 2011, Lutz et al. 2012, Bourg et al. 2013, Lutz et al. 2013) and likely reflects the varied habitats, high intensity of prior land use, and early stages of stand development at HF. Although we have much historical knowledge regarding land-use change at HF, the conditional regression random-forest modeling enabled us to explore more quantitatively how patterns of tree size and stem density for the seven most abundant species have been affected by tradeoffs between legacy effects of past land uses, management interventions, disturbances, and local-scale variation in stand structure and environmental conditions. This combination of quantitative modeling with historical knowledge contributes to a deeper understanding of historical human impacts on current forest structure.

For example, our modeling results suggested that $T$. canadensis diameters and stem densities across the full plot are most strongly associated with local stand structural characteristics and neighborhood effects, while stem densities are only moderately associated with land-use history. This result is consistent with the relatively undisturbed appearance of the older portion of the HF plot where T. canadensis is most common, its persistence through time for thousands of years (Foster and Zebryk 1993), and the exclusion of other species under its canopy. Tsuga canadensis is most abundant on land that was consistently used as a woodlot but never completely cleared for agriculture. The western portion of the plot was one of the few locations at HF that was mapped as T. canadensis forest in 1908 (Spurr 1956). The high abundance of $T$. canadensis is the result of its shade tolerance and deep crowns, which enable it to persist for decades, modify the understory environment by transmitting very little light, prevent other species from getting established (Canham et al. 1994), and gain dominance following partial cuttings, the death and subsequent salvage of $C$. dentata and $F$. grandifolia, and moderate damage from the 1938 hurricane (Foster et al. 1992, Motzkin et al. 1999, McLachlan et al. 2000). These same disturbances also likely led to growth increases and additional establishment of P. strobus (Hibbs 1982b), as the largest pine stems also occur on the western edge of the HF plot.

In contrast, modeling revealed stronger effects of both land-use history and stand structural variables on the sizes and stem densities of the other six dominant species. Field abandonment date and stand types present in the early- and mid- $20^{\text {th }}$ century are particularly strong predictors of diameters and densities of these species. This is consistent with recorded

Peer) reviewing PDF | (2021:08:64305:1:1:NEW 8 Nov 2021) 
356 historical knowledge. For example, Pinus strobus and Q. rubra are most abundant on areas that

357

358

359

360

361

362

363

364

365

366

367

368

369

370

371

372

373

374

375

376

377

378

379

380

381

382

383

384

385

386

387

388

389

390

391

392

393

394

395

were formerly pasture or fields in the mid- to late-1800s that also experienced intensive past silvicultural cuts, thinning, and weeding in the 1920s-1940s, and more severe damage from the 1938 hurricane (Motzkin et al. 1999, Hall 2005). Quercus rubra trees had larger mean diameters and crown sizes than $F$. grandifolia or $A$. rubrum, consistent with past investigations that highlighted the ability of $Q$. rubra to overtop canopy associates and rapidly expand laterally into gaps (Oliver 1978, Hibbs 1982a). Acer rubrum and B. alleghaniensis are more closely associated with mesic locations such as swamp borders with silt loam soils and low-lying sites with peaty soils in the northeast corner of the plot; indeed, random-forest models supported the relatively strong importance of soil type for these species and B. lenta relative to the other species. The south-central portion of the plot experienced the most intensive land use. It was the only area that experienced historical cultivation and multiple periods of subsequent clear-cutting, including a harvest in 1990. This area is dominated by smaller, multi-stemmed A. rubrum, Q. rubra, B. populifolia and B. papyrifera (grey and paper birch), and Prunus (cherry) species, which are much more common in forests that have experienced intense human impacts (Del Tredici 2001). The relationship between current stem-density patterns for A. rubrum and these two Betula species and intensive historical land-use activities can be explained by the ability of these species to sprout following cutting and take advantage of high-light environments (Burns and Honkala 1990).

Understory composition, dominated by woody shrubs, appears to be determined by soil drainage and the ability of individual species to tolerate standing water, poorly drained soils, or subtle topographic variation. Historically, the swamp contained pasture on its western edge and a woodlot in the remaining portion. Today, the wetland shrubs I. verticillata, Va. corymbosum, $L$. ligustrina, and Vi. nudum are found in high abundance in the central beaver swamp, which otherwise is devoid of trees. The northwest section of the plot has the highest elevation and is dominated by $K$. latifolia. Hamamelis virginiana appears to be restricted to a narrow elevation west of the swamp and in the southeast corner of the plot. Previous work at HF related $K$. latifolia abundance to nitrogen-poor sites and $H$. virginiana to continuously forested sites (Motzkin et al. 1999), which is consistent with our findings.

Across all species and size classes, the forest contains a preponderance $(>80,000)$ of small stems $(<10-\mathrm{cm}$ DBH) that exhibit a reverse-J size distribution. The high abundance of stems in this size class (e.g., several shrub species, T. canadensis, and A. rubrum) is in contrast to several other temperate forest plots (Lutz et al. 2012, Bourg et al. 2013, Lutz et al. 2013), and is more similar to results from tropical evergreen (Memiaghe et al. 2016) or Mediterranean forests (Gilbert et al. 2010). Most of the abundant overstory and all the abundant shrub species also have reverse-J distributions, indicative of stable populations and adequate regeneration. For overstory species, this likely is a result of the mix of even-age and varying-aged cohorts and single trees establishing following anthropogenic disturbances and natural gap-phase dynamics that are frequent in this region (Oliver and Stephens 1977, Hibbs 1982a, Pederson 2005). The greater ages of the shade-tolerant $T$. canadensis that occur on primary woodland are approaching a

Peer] reviewing PDF | (2021:08:64305:1:1:NEW 8 Nov 2021) 
396

397

398

399

400

401

402

403

404

405

406

407

408

409

410

411

412

413

414

415

416

417

418

419

420

421

422

423

424

425

426

427

428

429

430

431

432

433

434

435

structure and diameter distribution that resembles old-growth forest (D'Amato et al. 2008, Janowiak et al. 2008). In contrast, A. rubrum and Q. rubra had skewed unimodal size distributions more indicative of managed forests (Janowiak et al. 2008).

\section{Overstory spatial patterns}

We observed significant spatial clustering among abundant overstory species at all spatial scales examined. Aggregated species distribution patterns are common in both temperate (Hou et al. 2004, Hao et al. 2007, Wang et al. 2011) and tropical forests (Condit et al. 2000, Plotkin et al. 2000, Rejou-Mechain et al. 2011, Nguyen et al. 2016) . Both external factors (habitat heterogeneity) and internal factors (dispersal limitation, succession, gap dynamics) can lead to clumped distributions at various spatial scales (Getzin et al. 2008, Rejou-Mechain et al. 2011). Within the HF ForestGEO plot, high habitat heterogeneity caused by complex past land use (differing field abandonment dates followed by repeated cutting and thinning; Motzkin et al. 1999) has likely led to high densities of A. rubrum and Q. rubra stems in the central portion of the plot. These non-random patches of individuals with lower than average DBH (as seen in the mark correlation analysis) may reflect strong competition for light as seen elsewhere (Fibich et al. 2016). Similar patterns seen in B. alleghaniensis, B. lenta, P. strobus, and T. canadensis in close proximity to other conspecifics (0-20-m scale) likely reflect crowding effects, and for $T$. canadensis, the ability of thousands of small stems to persist in the understory for decades (Marshall 1927). These effects disappear at intermediate scales and even become positive at distances $>100 \mathrm{~m}$, indicating that trees greater than the mean DBH are more broadly distributed. The negative correlation observed for $F$. grandifolia at most spatial lags $\leq 150 \mathrm{~m}$ may be more reflective of its overall size distribution with most of its stems $<10 \mathrm{~cm}$ DBH. Beech-bark disease is present at $\mathrm{HF}$, and has likely contributed, along with past cutting, to the absence of large $F$. grandifolia in the plot.

Bivariate mark correlation functions have been underused in large, stem-mapped plots but hold great promise in ecological research (Velazquez et al. 2016). We used this method to examine the relationship between the size of individuals of $T$. canadensis, an important foundation species within the plot, with the size of six other important canopy species some distance away. Apart from Q. rubra, diameters of the other five species were positively correlated with the diameters of $T$. canadensis at all spatial scales. This pattern is consistent with T. canadensis being a foundation species in this forest (Buckley et al. 2016, Ellison et al. 2019), but it also simply could indicate a "habitat" effect: all these species are growing well everywhere and are found at a wide range of sizes. This effect was particularly strong for B. lenta and $P$. strobus, but weaker for A. rubrum, B. alleghaniensis, and F. grandifolia and disappeared after 100-150 m. Diameter of $Q$. rubra was on average smaller than expected by chance when within 20-80 $\mathrm{m}$ of $T$. canadensis. Historical factors play a role here, as the spatial distribution of these species highlight that oak abundance is the lowest within the T. canadensis-dominated portions of the plot that were woodlots and suggest that $T$. canadensis and the dense shade cast by their crowns limited establishment of the more intolerant $Q$. rubra. 
436

437

438

439

440

441

442

443

444

445

446

447

448

449

450

451

452

453

454

455

456

457

458

459

460

461

462

463

464

465

466

467

468

469

470

471

472

473

474

\section{Conclusions}

The HF ForestGEO plot is the largest mapped temperate-forest plot in North America and joins the growing array of temperate plots worldwide (Anderson-Teixeira et al. 2015). The species composition and aggregated spatial patterns within the plot are still being influenced by a land-use legacy of anthropogenic and natural disturbances that occurred decades to over a century ago. Despite extensive 20th-century harvesting, silvicultural thinning, and salvage operations following the 1938 hurricane, the most common overstory species in the HF ForestGEO plot today can best be predicted by longer-term land-use legacies represented by the 1908 forest type and the date of late 19th-century field abandonment, and tree neighborhood effects. At smaller scales, there is evidence of crowding effects of many common species, likely due to successional dynamics of these aggrading forests following intensive land use. The increasing importance of $T$. canadensis during the last century across the plot negatively affected the distribution of $Q$. rubra. Its location and five-year schedule of plot sampling highlight the plot as valuable long-term infrastructure that will complement Harvard Forest, LTER, NEON, and ForestGEO research efforts (Orwig et al. 2018). Because all woody stems $\geq 1 \mathrm{~cm} \mathrm{DBH}$ are mapped and measured, the data have been used in a variety of complementary ways including to examine species codispersion patterns and spatial patterns of species co-occurrence (Buckley et al. 2016, Case et al. 2016), help inform a simulation model of forest dynamics (SORTIE (Case et al. 2017)), assist with investigating crown allometry (Sullivan et al. 2017) and crown mapping (Hastings et al. 2020), develop maps of tree-mycorrhizal associations (Sousa et al. 2021) and aid in identifying statistical fingerprints of foundation species (Ellison et al. 2019). In addition, the data enable us to document changing species distribution patterns at an uncommonly large scale, while focusing on elements of the landscape that are often ignored, like beaver swamps and shrub thickets, and examine their contribution to overall forest structure and composition.

\section{Acknowledgements}

We thank the many field technicians who helped census the plot including Jerry Breault, Kyle Gay, Mike Babineau, Christian Foster, Jeff Hutchins, Tamara Martz, Elizabeth Barnes, Rachel DeMatte, Bianca Kubierschky, Ellen Kujawa, Audrey Lamb, Ben Misiuk, Finn Olcott, Hallie Schwab, Alida Mau, Joe Horn, Taylor Lucey, Brett Gelinas, Danelle Laflower, Sarah Meyers, and Kyle Krigest. We are grateful to John Wisnewski and the woods crew at HF for providing materials, supplies, and invaluable field assistance with plot logistics. Joel Botti and Frank 
475 Schiappa provided survey expertise to establish the 35-ha plot. Special thanks to Stuart Davies

476 and Rick Condit for field training, database assistance, and plot advice. Sean McMahon and

477 Suzanne Lao were extremely helpful with field planning, data questions, and many plot logistics.

478 Thanks to Jeannette Bowlen for administrative assistance, Emery Boose and Paul Siqueira for

479 help with plot coordinates, Brian Hall for map and GIS layer production, and Matthew Duveneck

480 and Danelle Laflower for assistance with figures. We also thank David Foster for his support and 481 assistance with plot design, location, and integration with other long-term studies at HF. We

482 thank 3 anonymous reviewers as well as Jonathan Thompson, Neil Pederson, Audrey Barker-

483 Plotkin and lab group members for providing critical comments on earlier versions of the

484 manuscript. There were no conflicts of interest.

485

486

487

488

489

\section{References}

490

491

492

493

494

495

496

497

498

499

500

501

502

503

504

505

506

507

508

509

510

511

512

513 United States Department of Agriculture Washington, DC.

Anderson-Teixeira, K. J., S. J. Davies, A. C. Bennett, E. B. Gonzalez-Akre, H. C.

Muller-Landau, S. Joseph Wright, K. Abu Salim, A. M. Almeyda Zambrano, A. Alonso, and J.

L. Baltzer. 2015. CTFS-Forest GEO: a worldwide network monitoring forests in an era of global change. Global Change Biology 21:528-549.

Birks, H. H., H. Birks, P. E. Kaland, and D. Moe. 1988. The cultural landscape: past, present and future. Cambridge University Press.

Boose, E., and E. Gould. 2019. Harvard Forest Climate Data since 1964. Harvard Forest Data

Archive: HF300. available online: http://harvardforest.fas.harvard.edu.

Bourg, N. A., W. J. McShea, J. R. Thompson, J. C. McGarvey, and X. Shen. 2013. Initial census, woody seedling, seed rain, and stand structure data for the SCBI SIGEO Large Forest Dynamics Plot. Ecology 94:2111-2112.

Brantley, S. T., M. L. Schulte, P. V. Bolstad, and C. F. Miniat. 2016. Equations for estimating biomass, foliage area, and sapwood of small trees in the southern Appalachians. Forest Science 62:414-421.

Breiman, L. 2001. Random forests. Machine learning 45:5-32.

Brown, J. K. 1976. Estimating shrub biomass from basal stem diameters. Canadian Journal of Forest Research 6:153-158.

Buckley, H. L., B. S. Case, and A. M. Ellison. 2016. Using codispersion analysis to characterize spatial patterns in species co-occurrences. Ecology 97:32-39.

Bürgi, M., L. Östlund, and D.J. Mladenoff. 2017. Legacy Effects of Human Land Use: Ecosystems as Time-Lagged Systems. Ecosystems 20: 94-103.

12 Burns, R. M., and B. H. Honkala. 1990. Silvics of North America. Volume 2. Hardwoods. 
514 Canham, C. D., A. C. Finzi, S. W. Pacala, and D. H. Burbank. 1994. Causes and consequences of 515 resource heterogeneity in forests: interspecific variation in light transmission by canopy trees.

516 Canadian Journal of Forest Research 24:337-349.

517 Case, B. S., H. L. Buckley, A. A. Barker-Plotkin, D. A. Orwig, and A. M. Ellison. 2017. When a

518 foundation crumbles: forecasting forest dynamics following the decline of the foundation species

519 Tsuga canadensis. Ecosphere 8:e01893.

520 Case, B. S., H. L. Buckley, A. Barker Plotkin, and A. Ellison. 2016. Using codispersion analysis

521 to quantify temporal changes in the spatial pattern of forest stand structure. Journal of Chilean

522 Statistics 7:3-15.

523 Chazdon, R. L. 2003. Tropical forest recovery: legacies of human impact and natural

524 disturbances. Perspectives in Plant Ecology, Evolution and Systematics 6:51-71.

525 Chojnacky, D. C., L. S. Heath, and J. C. Jenkins. 2014. Updated generalized biomass equations

526 for North American tree species. Forestry 87:129-151.

527 Condit, R. 1998. Tropical forest census plots: methods and results from Barro Colorado Island,

528 Panama and a comparison with other plots. Springer Science \& Business Media.

529 Condit, R. 2014. CTFS R Package. Smithsonian Tropical Research Institute.

530 Condit, R., P. S. Ashton, P. Baker, S. Bunyavejchewin, S. Gunatilleke, N. Gunatilleke, S. P.

531 Hubbell, R. B. Foster, A. Itoh, and J. V. LaFrankie. 2000. Spatial patterns in the distribution of

532 tropical tree species. Science 288:1414-1418.

533 Connolly, B. J. 1981. Shrub Biomass--soil Relationships in Minnesota Wetlands. University of

534 Minnesota.

535 D'Amato, A. W., D. A. Orwig, and D. R. Foster. 2008. The influence of successional processes

536 and disturbance on the structure of Tsuga canadensis forests. Ecological Applications 18:1182-

5371199.

538 Del Tredici, P. 2001. Sprouting in temperate trees: a morphological and ecological review. The

539 Botanical Review 67:121-140.

540 Dickinson, Y. L., and E. K. Zenner. 2010. Allometric equations for the aboveground biomass of

541 selected common eastern hardwood understory species. Northern Journal of Applied Forestry

542 27:160-165.

543 Ellison, A. M. 2019. Foundation species, non-trophic interactions, and the value of being

544 common. Iscience 13:254-268.

545 Ellison, A. M., M. S. Bank, B. D. Clinton, E. A. Colburn, K. Elliott, C. R. Ford, D. R. Foster, B.

546 D. Kloeppel, J. D. Knoepp, and G. M. Lovett. 2005. Loss of foundation species: consequences

547 for the structure and dynamics of forested ecosystems. Frontiers in Ecology and the Environment $548 \quad 3: 479-486$.

549 Ellison, A. M., H. L. Buckley, B. S. Case, D. Cardenas, Á. J. Duque, J. A. Lutz, J. A. Myers, D.

550 A. Orwig, and J. K. Zimmerman. 2019. Species Diversity Associated with Foundation Species in

551 Temperate and Tropical Forests. Forests 10:128. 
552 Ellison, A. M., M. Lavine, P. B. Kerson, A. A. Barker Plotkin, and D. A. Orwig. 2014. Building 553 a foundation: Land-use history and dendrochronology reveal temporal dynamics of a Tsuga 554 canadensis (Pinaceae) forest. Rhodora 116:377-427.

555 Fibich, P., J. Lepš, V. Novotný, P. Klimeš, J. Těšitel, K. Molem, K. Damas, and G. D. Weiblen.

556 2016. Spatial patterns of tree species distribution in New Guinea primary and secondary lowland 557 rain forest. Journal of Vegetation Science 27:328-339.

558 Finzi, A. C., M.-A. Giasson, A. A. Barker Plotkin, J. D. Aber, E. R. Boose, E. A. Davidson, M. 559 C. Dietze, A. M. Ellison, S. D. Frey, E. Goldman, T. F. Keenan, J. M. Melillo, J. W. Munger, K. 560 J. Nadelhoffer, S. V. Ollinger, D. A. Orwig, N. Pederson, A. D. Richardson, K. Savage, J. Tang, 561 J. R. Thompson, C. A. Williams, S. C. Wofsy, Z. Zhou, and D. R. Foster. 2020. Carbon budget 562 of the Harvard Forest Long-Term Ecological Research site: pattern, process, and response to 563 global change. Ecological Monographs 90(4):e01423. 10.1002/ecm.1423.

564 Fisher, R. T. 1933. New England forests: biological factors. New England's Prospect. American 565 Geographical Society. Special Publication:213-223.

566 Foster, D. 2014. Hemlock: a forest giant on the edge. Yale University Press, New Haven, 567 Connecticut, USA.

568 Foster, D. R. 1992. Land-use history (1730-1990) and vegetation dynamics in central New 569 England, USA. Journal of Ecology:753-771.

570 Foster, D. R., and J. Aber. 2004. Forests in Time. Ecosystem Structure and Function as a

571 Consequence of 1000 Years of Change. Synthesis volume of the Harvard Forest LTER Program.

572 Yale University Press, New Haven, Connecticut, USA.

573 Foster, D. R., and E. R. Boose. 1992. Patterns of forest damage resulting from catastrophic wind 574 in central New England, USA. Journal of Ecology:79-98.

575 Foster, D. R., G. Motzkin, and B. Slater. 1998. Land-use history as long-term broad-scale

576 disturbance: regional forest dynamics in central New England. Ecosystems 1:96-119.

577 Foster, D. R., T. Zebryk, P. Schoonmaker, and A. Lezberg. 1992. Post-settlement history of

578 human land-use and vegetation dynamics of a Tsuga canadensis (hemlock) woodlot in central

579 New England. Journal of Ecology:773-786.

580 Foster, D. R., and T. M. Zebryk. 1993. Long-term vegetation dynamics and disturbance history

581 of a Tsuga-dominated forest in New England. Ecology 74:982-998.

582 Fox, E. W., R. A. Hill, S. G. Leibowitz, A. R. Olsen, D. J. Thornbrugh, and M. H. Weber. 2017.

583 Assessing the accuracy and stability of variable selection methods for random forest modeling in 584 ecology. Environmental Monitoring and Assessment 189:1-20.

585 Getzin, S., T. Wiegand, K. Wiegand, and F. He. 2008. Heterogeneity influences spatial patterns 586 and demographics in forest stands. Journal of Ecology 96:807-820.

587 Gilbert, G. S., E. Howard, B. Ayala-Orozco, M. Bonilla-Moheno, J. Cummings, S. Langridge, I. 588 M. Parker, J. Pasari, D. Schweizer, and S. Swope. 2010. Beyond the tropics: forest structure in a 589 temperate forest mapped plot. Journal of Vegetation Science 21:388-405. 
590 Glitzenstein, J. S., C. D. Canham, M. J. McDonnell, and D. R. Streng. 1990. Effects of 591 environment and land-use history on upland forests of the Cary Arboretum, Hudson Valley, New

592 York. Bulletin of the Torrey Botanical Club:106-122.

593 Griffith, G., J. Omernik, S. Pierson, and C. Kiilsgaard. 1994. The Massachusetts Ecological

594 Regions Project. US Environmental Protection Agency. Environmental Research Laboratory, 595 Corvallis, OR, USA.

596 Grigal, D. F., and L. F. Ohmann. 1977. Biomass estimation for some shrubs from northeastern 597 Minnesota.

598 Haines, A. 2011. New England Wild Flower Society's Flora Novae Angliae: a manual for the 599 identification of native and naturalized higher vascular plants of New England. Yale University 600 Press.

601 Hall, B. 2005. Harvard Forest Properties GIS. Harvard Forest Data Archive, HF110.

602 Hall, B., G. Motzkin, D. R. Foster, M. Syfert, and J. Burk. 2002. Three hundred years of forest 603 and land-use change in Massachusetts, USA. Journal of Biogeography 29:1319-1335.

604 Hao, Z., J. Zhang, B. Song, J. Ye, and B. Li. 2007. Vertical structure and spatial associations of 605 dominant tree species in an old-growth temperate forest. Forest Ecology and Management 252:160611.

607 Hastings, J. H., S. V. Ollinger, A. P. Ouimette, R. Sanders-DeMott, M. W. Palace, M. J. Ducey, 608 F. B. Sullivan, D. Basler, and D. A. Orwig. 2020. Tree Species Traits Determine the Success of 609 LiDAR-Based Crown Mapping in a Mixed Temperate Forest. Remote Sensing 12:309.

610 Hibbs, D. E. 1982a. Gap dynamics in a hemlock-hardwood forest. Canadian Journal of Forest 611 Research 12:522-527.

612 Hibbs, D. E. 1982b. White pine in the transition hardwood forest. Canadian Journal of Botany 613 60:2046-2053.

614 Hogan, J. A., J. K. Zimmerman, J. Thompson, C. J. Nytch, and M. Uriarte. 2016. The interaction 615 of land-use legacies and hurricane disturbance in subtropical wet forest: twenty-one years of 616 change. Ecosphere 7:e01405.

617 Hothorn, T., K. Hornik, C. Strobl, A. Zeileis, and M. T. Hothorn. 2013. Package 'party'.

618 Citeseer.

619 Hothorn, T., K. Hornik, and A. Zeileis. 2006. Unbiased recursive partitioning: A conditional 620 inference framework. Journal of Computational and Graphical statistics 15:651-674.

621 Hou, J., X. Mi, C. Liu, and K. Ma. 2004. Spatial patterns and associations in a Quercus-Betula 622 forest in northern China. Journal of Vegetation Science 15:407-414.

623 Illian, J., A. Penttinen, H. Stoyan, and D. Stoyan. 2008. Statistical analysis and modelling of 624 spatial point patterns (Vol. 70). John Wiley \& Sons.

625 Jacquemyn, H., P. Endels, O. Honnay, and T. Wiegand. 2010. Evaluating management 626 interventions in small populations of a perennial herb Primula vulgaris using spatio-temporal 627 analyses of point patterns. Journal of Applied Ecology 47:431-440. 
628 Janowiak, M. K., L. M. Nagel, and C. R. Webster. 2008. Spatial scale and stand structure in 629 northern hardwood forests: implications for quantifying diameter distributions. Forest Science 630 54:497-506.

631 Jenkins, J. C., D. C. Chojnacky, L. S. Heath, and R. A. Birdsey. 2004. Comprehensive database 632 of diameter-based biomass regressions for North American tree species. Gen. Tech. Rep. NE-

633 319. Newtown Square, PA: US Department of Agriculture, Forest Service, Northeastern

634 Research Station. 45 p.[1 CD-ROM]. 319.

635 Lutz, J. A., A. J. Larson, J. A. Freund, M. E. Swanson, and K. J. Bible. 2013. The importance of 636 large-diameter trees to forest structural heterogeneity. PLOS ONE 8:e82784.

637 Lutz, J. A., A. J. Larson, M. E. Swanson, and J. A. Freund. 2012. Ecological importance of 638 large-diameter trees in a temperate mixed-conifer forest. PLOS ONE 7:e36131.

639 Marshall, R. 1927. The growth of hemlock before and after release from suppression. Harvard 640 Forest.

641 McLachlan, J. S., D. R. Foster, and F. Menalled. 2000. Anthropogenic ties to late-successional 642 structure and composition in four New England hemlock stands. Ecology 81:717-733.

643 Memiaghe, H. R., J. A. Lutz, L. Korte, A. Alonso, and D. Kenfack. 2016. Ecological importance 644 of small-diameter trees to the structure, diversity and biomass of a tropical evergreen forest at 645 Rabi, Gabon. PLOS ONE 11:e0154988.

646 Mi, C., F. Huettmann, Y. Guo, X. Han, and L. Wen. 2017. Why choose Random Forest to 647 predict rare species distribution with few samples in large undersampled areas? Three Asian

648 crane species models provide supporting evidence. PeerJ 5:e2849.

649 Mohapatra, J., C. P. Singh, M. Hamid, A. Verma, S. C. Semwal, B. Gajmer, A. A. Khuroo, A.

650 Kumar, M. C. Nautiyal, and N. Sharma. 2019. Modelling Betula utilis distribution in response to 651 climate-warming scenarios in Hindu-Kush Himalaya using random forest. Biodiversity and 652 Conservation 28:2295-2317.

653 Motzkin, G., D. Foster, A. Allen, J. Harrod, and R. Boone. 1996. Controlling site to evaluate 654 history: vegetation patterns of a New England sand plain. Ecological Monographs 66:345-365.

655 Motzkin, G., P. Wilson, D. R. Foster, and A. Allen. 1999. Vegetation patterns in heterogeneous

656 landscapes: the importance of history and environment. Journal of Vegetation Science 10:903-

657920.

658 Nguyen, H. H., J. Uria-Diez, and K. Wiegand. 2016. Spatial distribution and association patterns 659 in a tropical evergreen broad-leaved forest of north-central Vietnam. Journal of Vegetation 660 Science 27:318-327.

661 Oliver, C. D. 1978. The development of northern red oak in mixed stands in central New

662 England. Yale School of Forestry \& Environmental Studies Bulletin Series. 8.

663 Oliver, C. D., and E. P. Stephens. 1977. Reconstruction of a mixed-species forest in central New 664 England. Ecology 58:562-572.

665 Orwig, D., D. Foster, and A. Ellison. 2015. Harvard Forest CTFS-ForestGEO mapped forest plot 666 since 2014. Harvard Forest Data Archive: HF253. Available online:

667 http://harvardforest.fas.harvard.edu. 
668 Orwig, D. A., A. A. Barker Plotkin, E. A. Davidson, H. Lux, K. E. Savage, and A. M. Ellison. 669 2013. Foundation species loss affects vegetation structure more than ecosystem function in a 670 northeastern USA forest. PeerJ 1:e41.

671 Orwig, D. A., P. Boucher, I. Paynter, E. Saenz, Z. Li, and C. Schaaf. 2018. The potential to 672 characterize ecological data with terrestrial laser scanning in Harvard Forest, MA. Interface 673 Focus Apr 6;8(2):20170044.

674 Pederson, N. 2005. Climatic Sensitivity and Growth of Southern Temperate Tress in the Eastern 675 US: Implicatins for the Carbon Cycle. Columbia University New York, New York.

676 Perala, D., and D. Alban. 1994. Allometric biomass estimators for aspen-dominated ecosystems

677 in the Upper Great Lakes. Research Paper NC-314. US Department of Agriculture, Forest

678 Service, North Central Research Station, St. Paul, MN.

679 Plotkin, J. B., M. D. Potts, N. Leslie, N. Manokaran, J. LaFrankie, and P. S. Ashton. 2000.

680 Species-area curves, spatial aggregation, and habitat specialization in tropical forests. Journal of 681 Theoretical Biology 207:81-99.

682 R Core Team. 2013. R: A language and environment for statistical computing.

683 Rackham, O. 1986. The history of the countryside. Dent London.

684 Rasband, W. 2012. ImageJ: Image processing and analysis in Java. Astrophysics Source Code

685 Library.

686 Raup, H. M., and R. E. Carlson. 1941. The history of land use in the Harvard Forest. The

687 Harvard Forest Bulletin 20:4-62.

688 Réjou-Méchain, M., O. Flores, N. Bourland, J. L. Doucet, R. F. Fétéké, A. Pasquier, and O. J. 689 Hardy. 2011. Spatial aggregation of tropical trees at multiple spatial scales. Journal of Ecology 690 99:1373-1381.

691 Rhemtulla J.M., D.J. Mladenoff, and M.K. Clayton. 2009. Legacies of historical land use on

692 regional forest composition and structure in Wisconsin, USA (mid-1800s to 1930s to 2000s).

693 Ecological Applications 19:1061-78.

694 Roussopoulos, P. J., and R. M. Loomis. 1979. Weights and dimensional properties of shrubs and 695 small trees of the Great Lakes conifer forest. Research Paper NC-178. St. Paul, MN: US Dept. of 696 Agriculture, Forest Service, North Central Forest Experiment Station 178.

697 Rowlands, W. 1941. Damage to even-aged stands in Petersham, Massachusetts by the 1938

698 hurricane as influenced by stand condition. MF thesis. Harvard University, Cambridge,

699 Massachusetts.

700 Russell, E. W. B. 1997. People and the land through time: linking ecology and history. Yale 701 University Press.

702 Shearman, T. M., J. M. Varner, S. M. Hood, C. A. Cansler, and J. K. Hiers. 2019. Modelling 703 post-fire tree mortality: Can random forest improve discrimination of imbalanced data?

704 Ecological Modelling 414:108855.

705 Simmons, C. S. 1941. Prospect Hill 1941 Soil Survey. Harvard Forest Archives. 
706 Smith, W. B., and G. J. Brand. 1983. Allometric biomass equations for 98 species of herbs, 707 shrubs, and small trees. Research Note NC-299. St. Paul, MN: US Dept. of Agriculture, Forest 708 Service, North Central Forest Experiment Station 299.

709 Sousa, D., J.B., Fisher, F.R. Galvan, R.P. Pavlick, S. Cordell, T.W. Giambelluca, C.P. Giardina, 710 G.S. Gilbert, F. Imran-Narahari, C.M. Litton, and J.A. Lutz, J.A. 2021. Tree canopies reflect 711 mycorrhizal composition. Geophysical Research Letters, 48(10), p.e2021GL092764.

712 Spurr, S. H. 1956. Forest associations in the Harvard Forest. Ecological Monographs 26:245713262.

714 Strobl, C., A.-L. Boulesteix, A. Zeileis, and T. Hothorn. 2007. Bias in random forest variable 715 importance measures: Illustrations, sources, and a solution. BMC bioinformatics 8:25.

716 Sullivan, F. B., M. J. Ducey, D. A. Orwig, B. Cook, and M. W. Palace. 2017. Comparison of 717 lidar-and allometry-derived canopy height models in an eastern deciduous forest. Forest Ecology 718 and Management 406:83-94.

719 Telfer, E. 1969. Weight-diameter relationships for 22 woody plant species. Canadian Journal of 720 Botany 47:1851-1855.

721 Ter-Mikaelian, M. T., and M. D. Korzukhin. 1997. Biomass equations for sixty-five North 722 American tree species. Forest Ecology and Management 97:1-24.

723 Thompson, J., N. Brokaw, J. K. Zimmerman, R. B. Waide, E. M. Everham, D. J. Lodge, C. M.

724 Taylor, D. García-Montiel, and M. Fluet. 2002. Land use history, environment, and tree 725 composition in a tropical forest. Ecological Applications 12:1344-1363.

726 Thompson, J. R., D. N. Carpenter, C. V. Cogbill, and D. R. Foster. 2013. Four centuries of 727 change in northeastern United States forests. PLOS ONE 8:e72540.

728 Turner, B., W. Clark, R. Kates, J. Richards, and J. Mathews. 1990. The earth as transformed by 729 human action: global and regional changes in the biosphere over the past 300 years.

730 Van Gemerden, B. S., H. Olff, M. P. Parren, and F. Bongers. 2003. The pristine rain forest?

731 Remnants of historical human impacts on current tree species composition and diversity. Journal 732 of Biogeography 30:1381-1390.

733 Velázquez, E., I. Martínez, S. Getzin, K. A. Moloney, and T. Wiegand. 2016. An evaluation of 734 the state of spatial point pattern analysis in ecology. Ecography 39:1042-1055.

735 Wang, X., T. Wiegand, Z. Hao, B. Li, J. Ye, and F. Lin. 2010. Species associations in an 736 old-growth temperate forest in north-eastern China. Journal of Ecology 98:674-686.

737 Wang, X., T. Wiegand, A. Wolf, R. Howe, S. J. Davies, and Z. Hao. 2011. Spatial patterns of 738 tree species richness in two temperate forests. Journal of Ecology 99:1382-1393.

739 Wartluft, J. L. 1977. Weights of the Small Appalachian Hardwood Trees and Components. Res.

740 Pap. NE-366. Upper Darby, PA: US Department of Agriculture, Forest Service, Northeastern

741 Forest Experiment Station. 4p. 366.

742 Westveld, M. 1956. Natural forest vegetation zones of New England. Journal of Forestry 54:332743338.

744 Wiegand, T., and K. A. Moloney. 2004. Rings, circles, and null-models for point pattern analysis 745 in ecology. Oikos 104:209-229. 
746 Wiegand, T., F. He, and S. P. Hubbell. 2013. A systematic comparison of summary

747 characteristics for quantifying point patterns in ecology. Ecography 36:92-103.

748 Wiegand, T., and K. A. Moloney. 2014. Handbook of spatial point-pattern analysis in ecology.

749 Chapman and Hall/CRC, Baca Raton, FL.

750 Young, H. E., J. H. Ribe, and K. Wainwright. 1980. Weight tables for tree and shrub species in 751 Maine. Maine. Life Sciences and Agriculture Experiment Station. Miscellaneous report (USA). 752 Zhang, Z.H., G. Hu, J.D. Zhu, D.H. Luo, and J. Ni. 2010. Spatial patterns and interspecific 753 associations of dominant tree species in two old-growth karst forests, SW China. Ecological 754 research, 25(6):1151-1160.

755 Zimmerman, J. K., T. M. Aide, M. Rosario, M. Serrano, and L. Herrera. 1995. Effects of land 756 management and a recent hurricane on forest structure and composition in the Luquillo 757 Experimental Forest, Puerto Rico. Forest Ecology and Management 77:65-76. 


\section{Figure 1}

The $500 \times 700$ m ForestGEO plot located in the town of Petersham, MA on the Prospect Hill tract of HF (upper right panel).

Locations of three eddy-flux towers (that measure net ecosystem exchange of carbon and water between the atmosphere and the ecosystem), old forest roads, stone walls (denoted by dotted lines), and the central swamp area are superimposed on topographic contour lines (lower panel). 


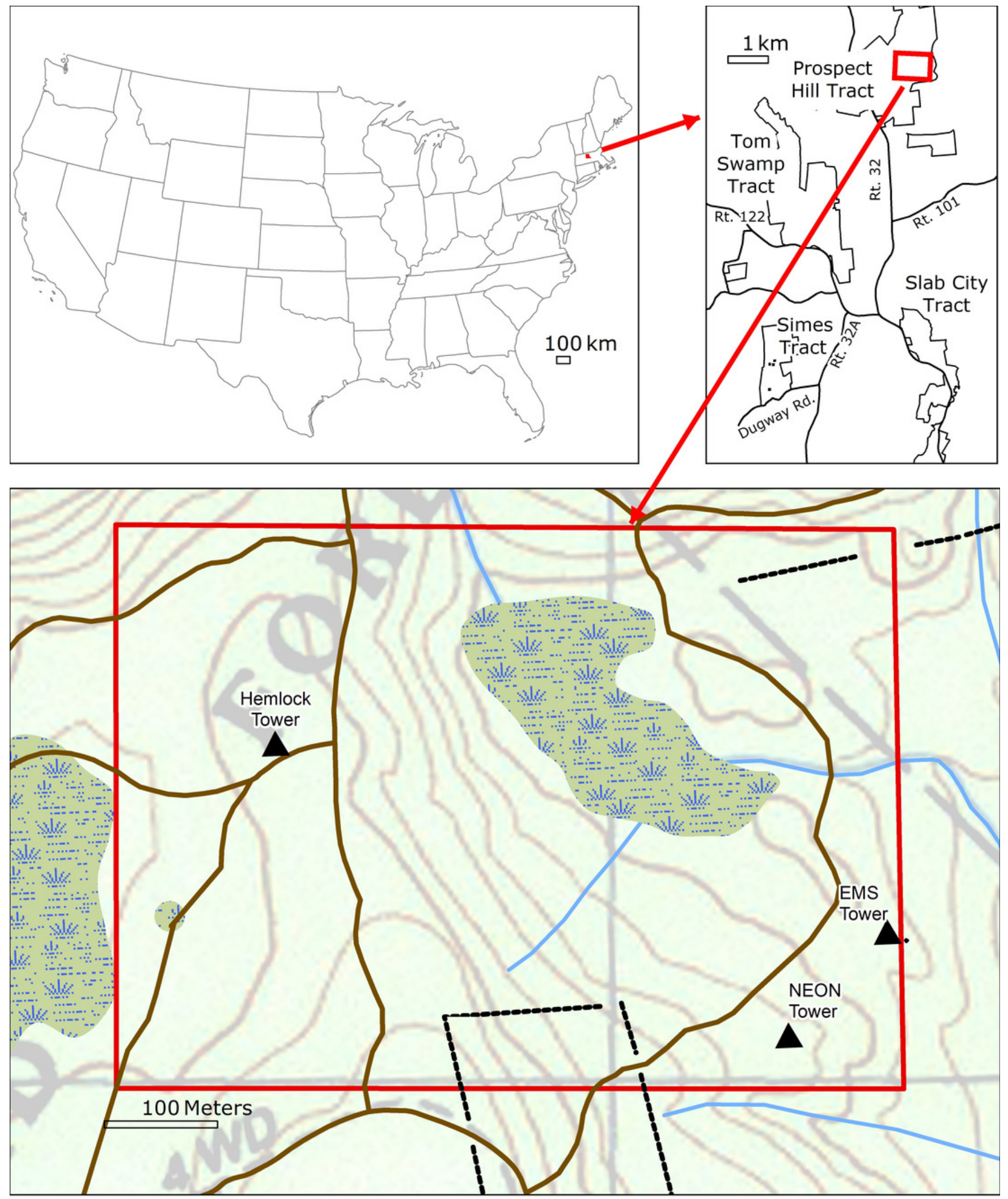

$\square$ Forest Dynamics Plot

$\Delta$ Research Towers

Stream
Woods Road or Trail

coso Stone Wall

1...... Swamp 
Figure 2

Historical GIS layers of the HF ForestGEO plot.

Location of a) historical fields and their agricultural date of abandonment, b) forest stands as described in 1908, and c) soil type. GIS layers obtained from Harvard Forest Document Archive HF 110. 
a)

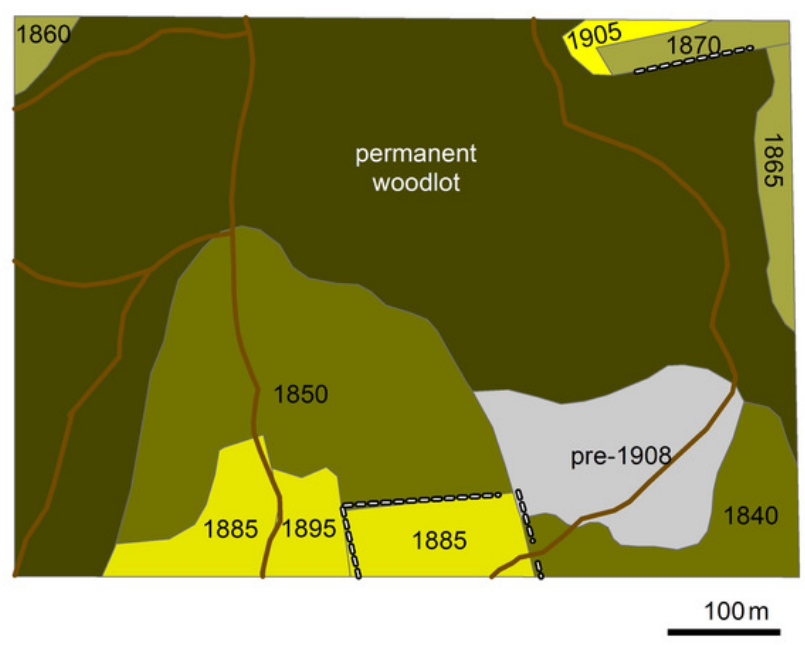

b)

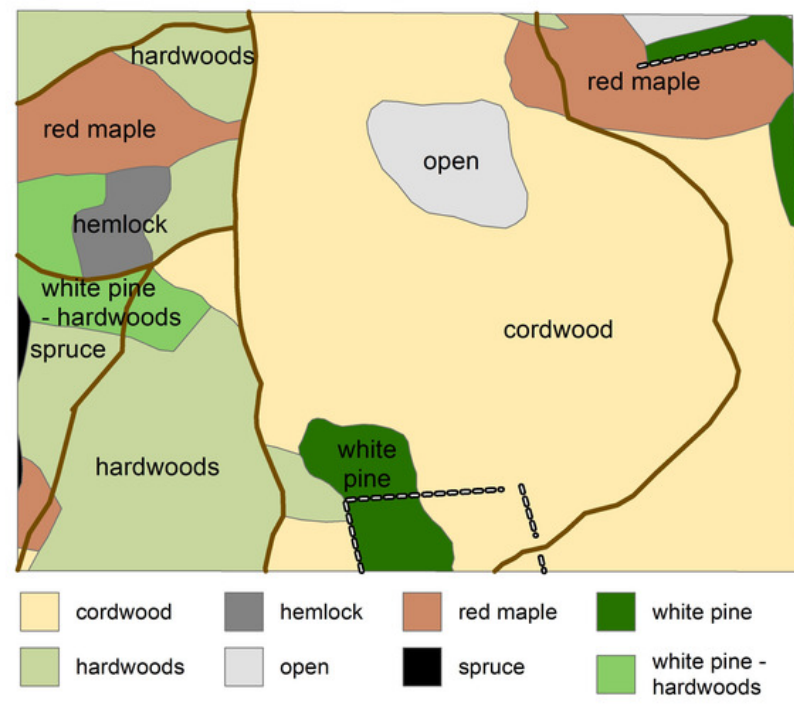

c)

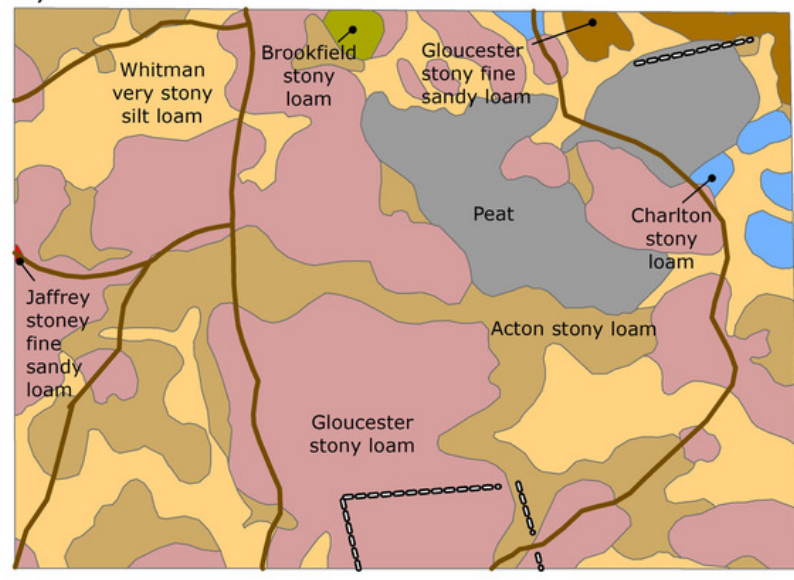

Gloucester stony loam

Gloucester stony fine sandy loam

Whitman very stony silt loam

Charlton stony loam

Acton stony loam

Peat

Brookfield stony loam

Jaffrey stony fine sandy loam

Peer) reviewing PDF | (2021:08:64305:1:1:NEW 8 Nov 2021) 
Figure 3

Diameter distribution of the seven most common overstory species within the HF ForestGEO plot. 
Tsuga canadensis

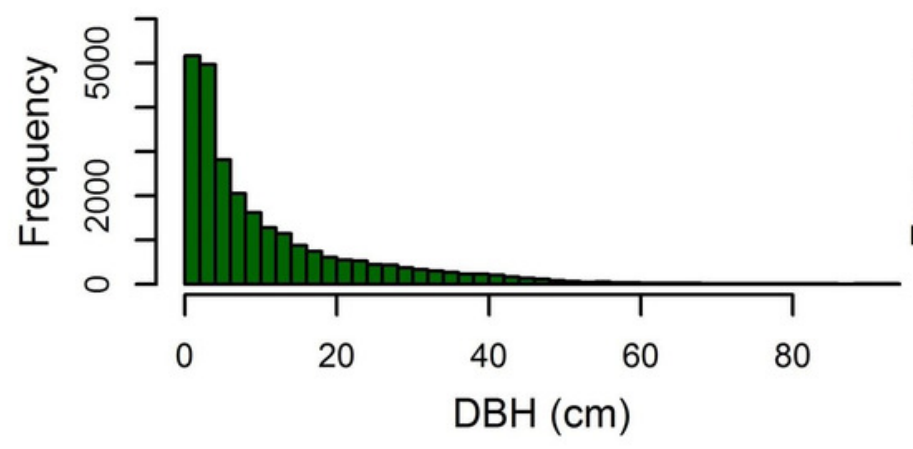

Quercus rubra
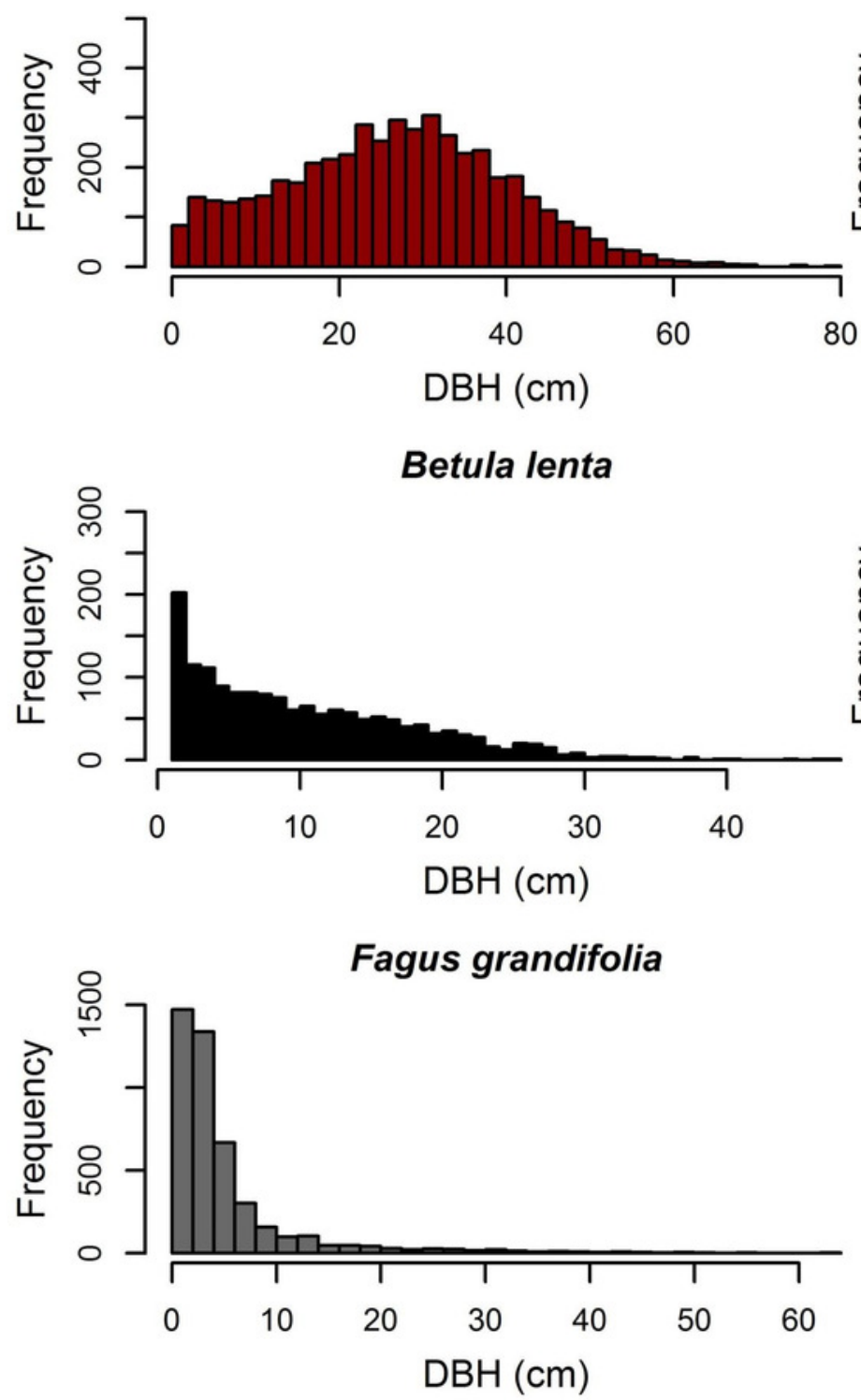

Acer rubrum

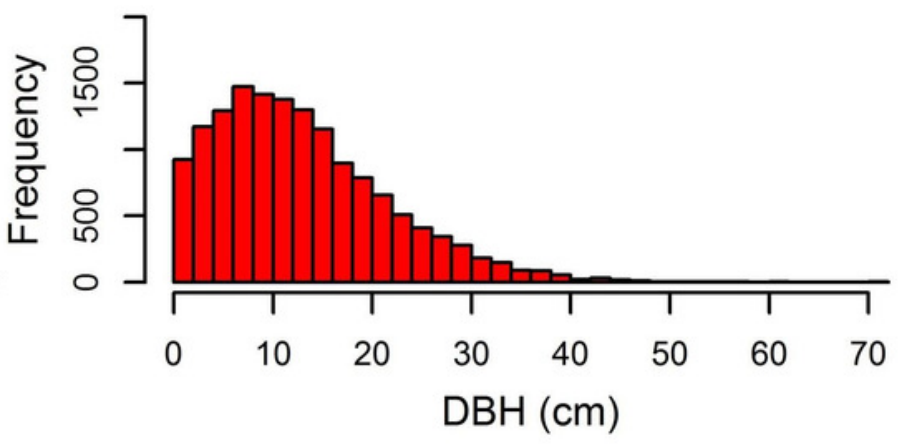

Pinus strobus

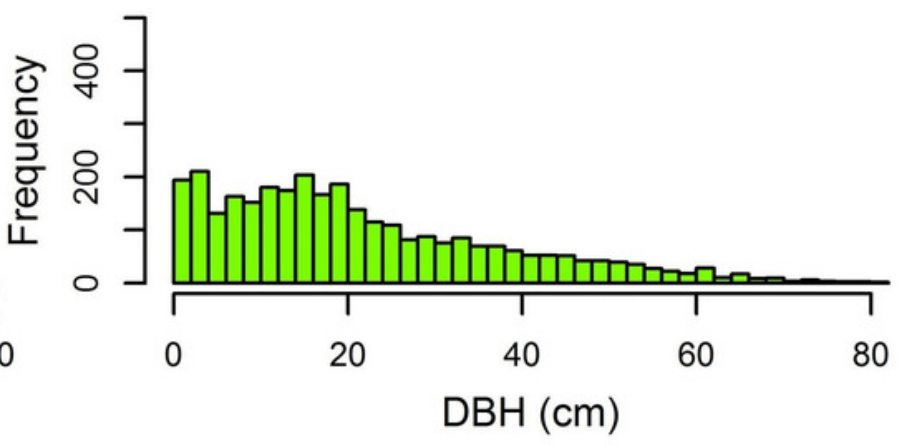

Betula alleghaniensis

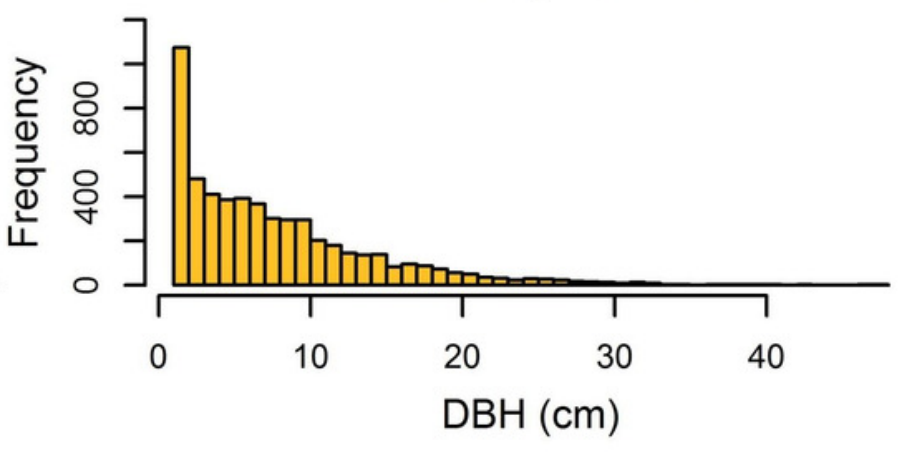


Figure 4

Diameter distribution of the six most common understory species within the HF ForestGEO plot. 

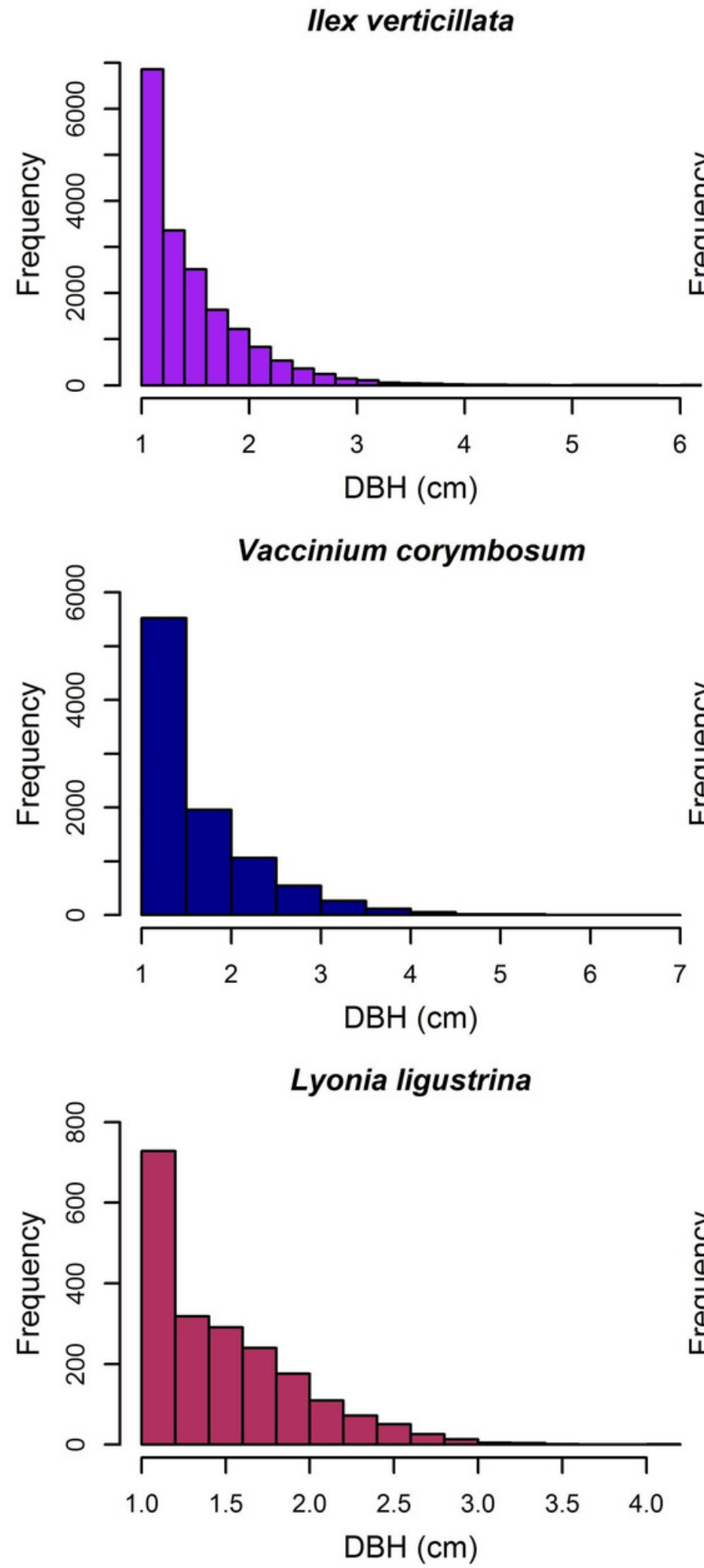

Kalmia latifolia

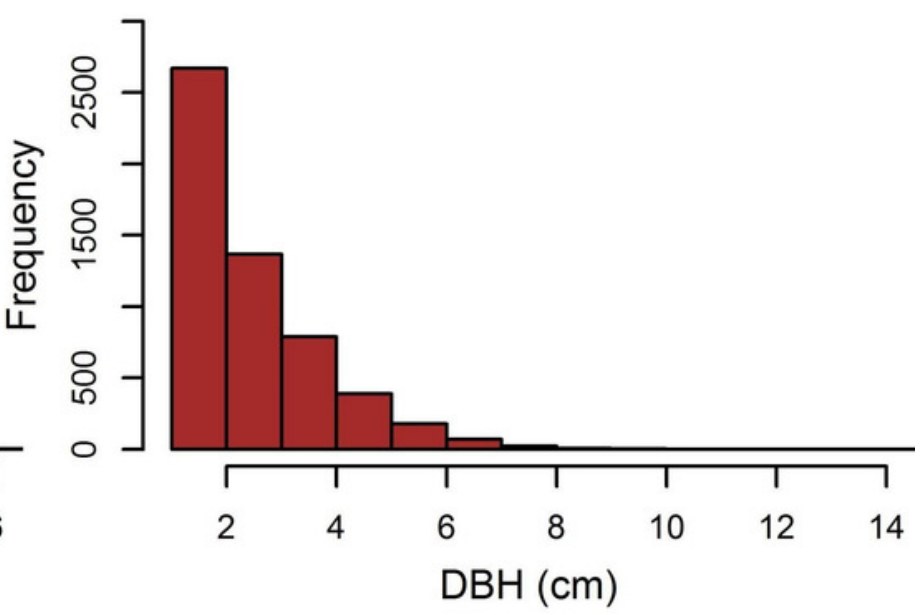

Hamamelis virginiana

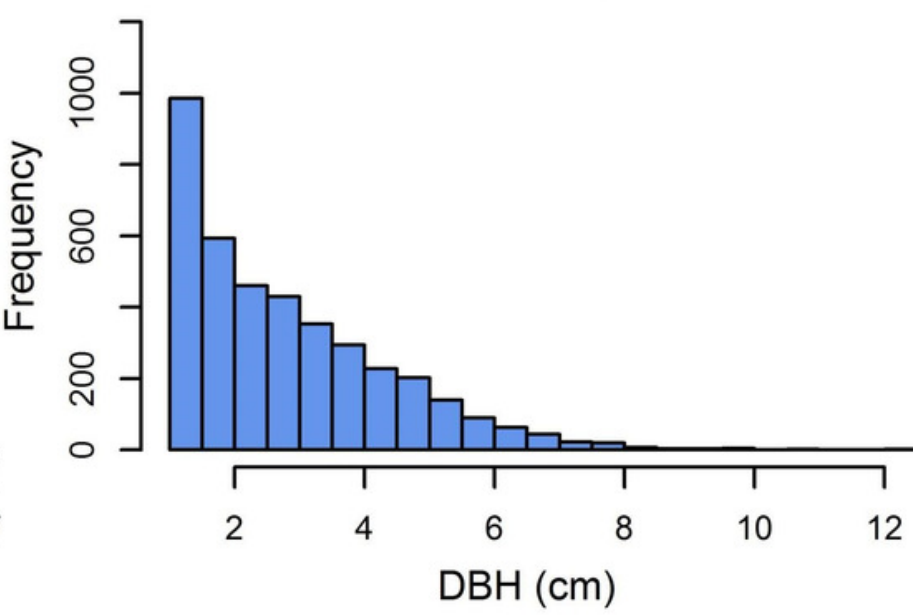

Viburnum nudum

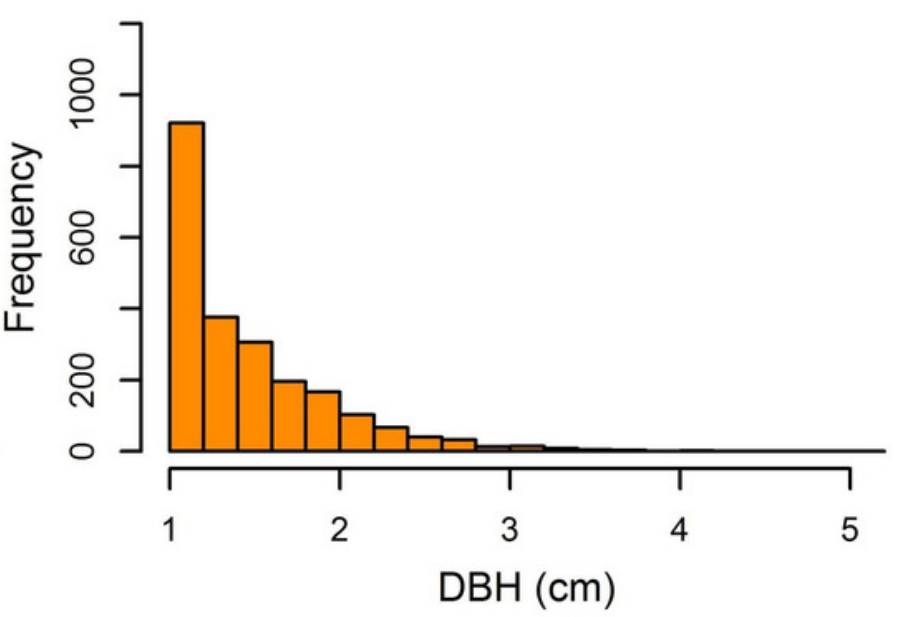


Figure 5

Spatial distribution of stems $\geq 1 \mathrm{~cm}$ dbh of the seven most common overstory species within the HF ForestGEO plot with $3 \mathrm{~m}$ elevation contour lines. 
- Tsuga canadensis

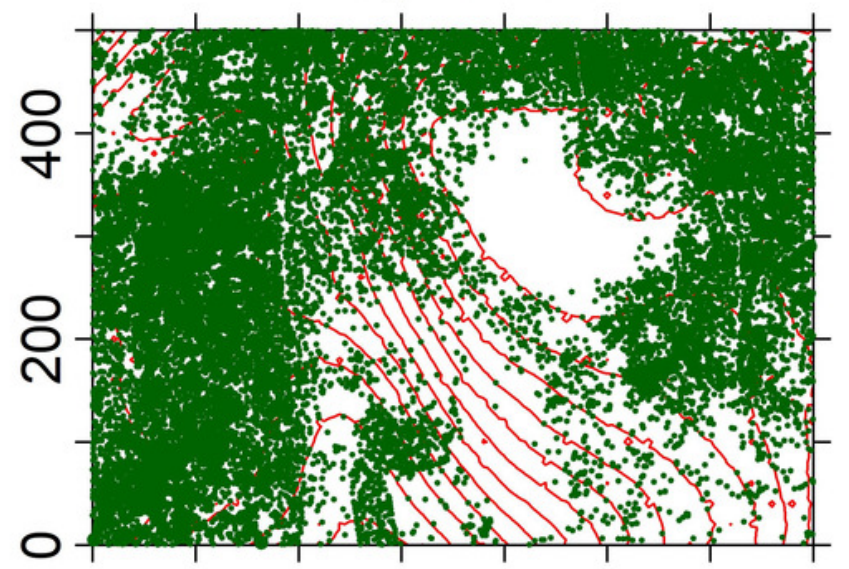

- Quercus rubra

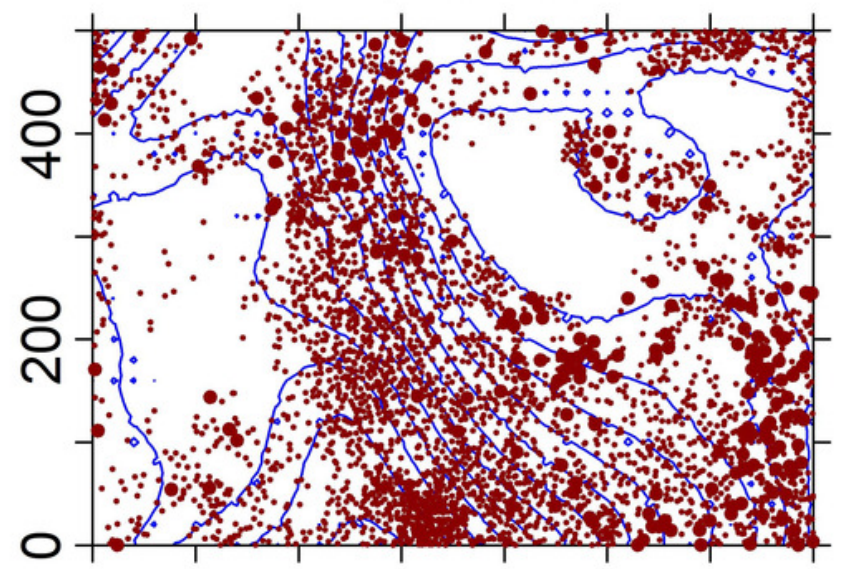

- Betula alleghaniensis • Betula lenta

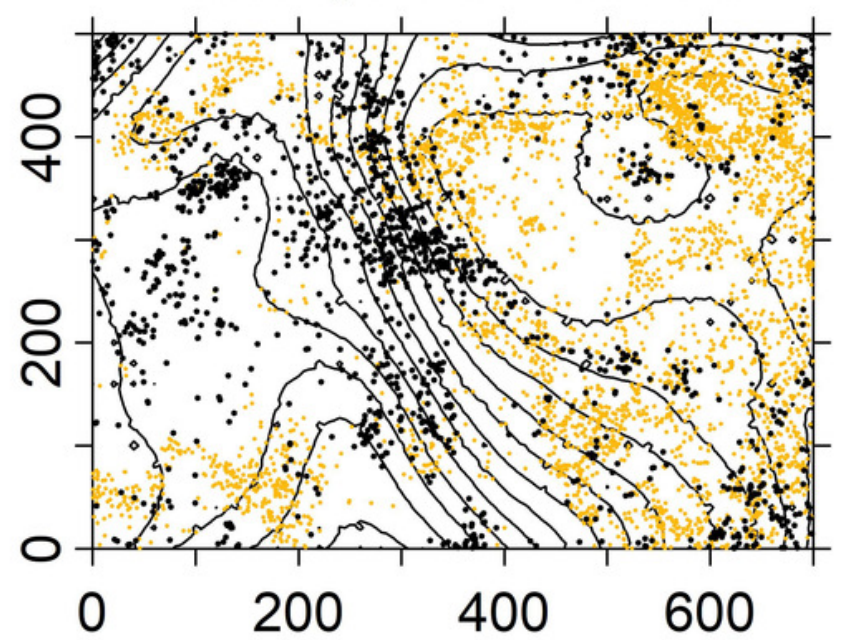

- Acer rubrum

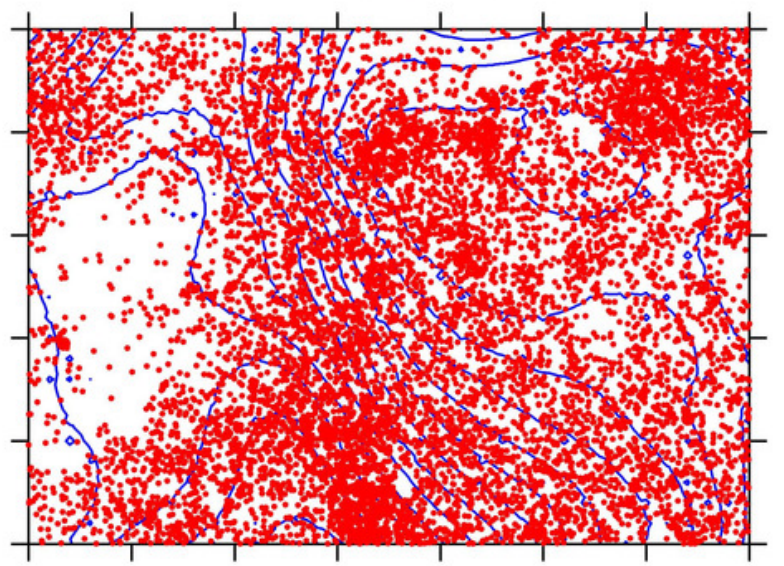

- Pinus strobus

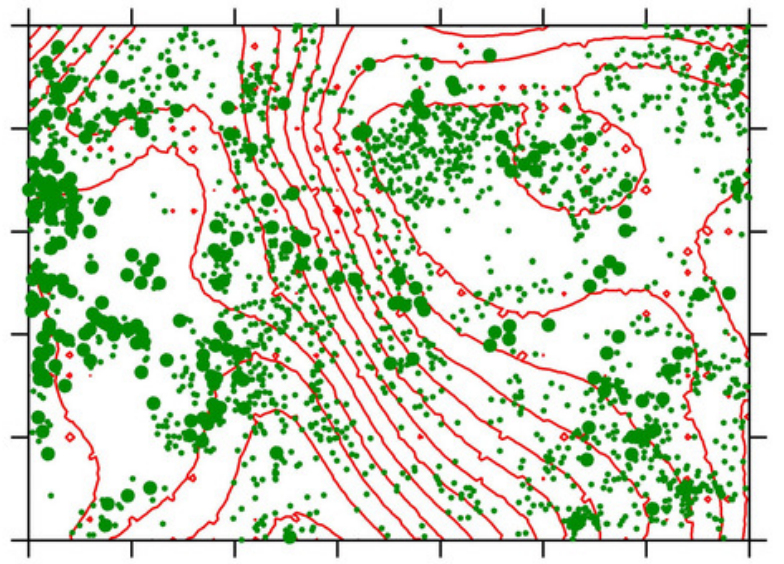

- Fagus grandifolia

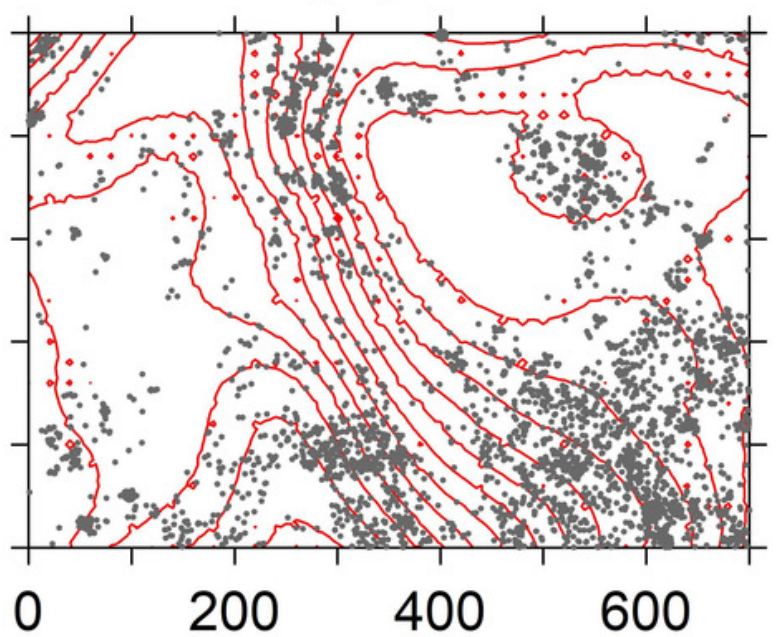


Figure 6

Spatial distribution of stems $\geq 1 \mathrm{~cm}$ dbh of the six most common understory species within the HF ForestGEO plot with $3 \mathrm{~m}$ elevation contour lines. 
- Ilex verticillata

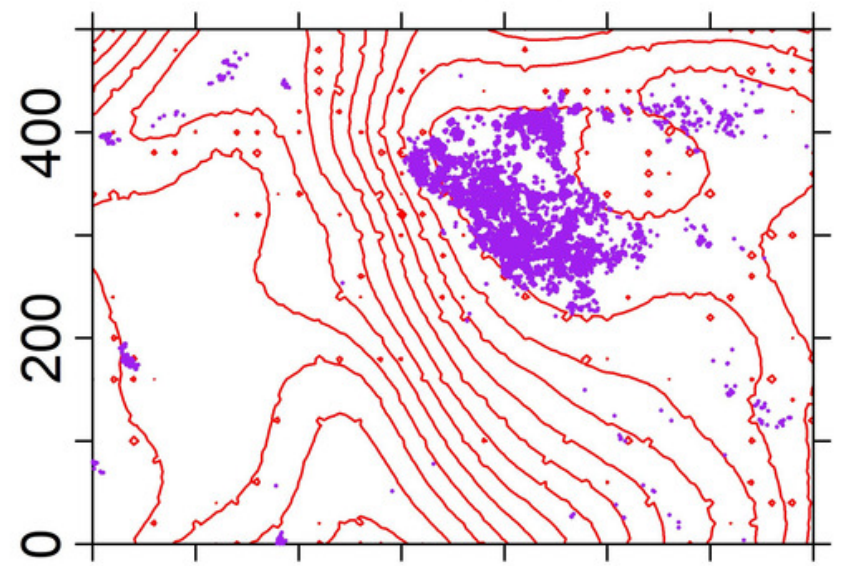

- Vaccinium corymbosum

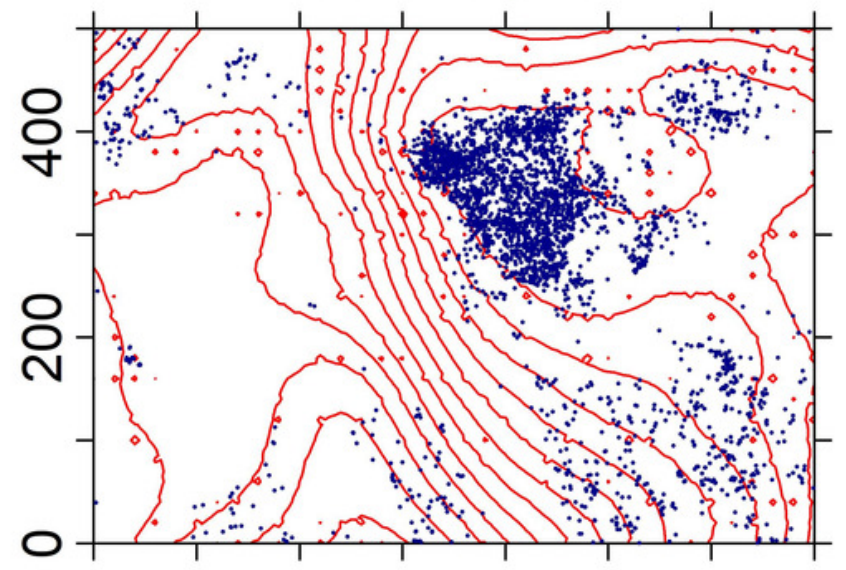

- Lyonia ligustrina

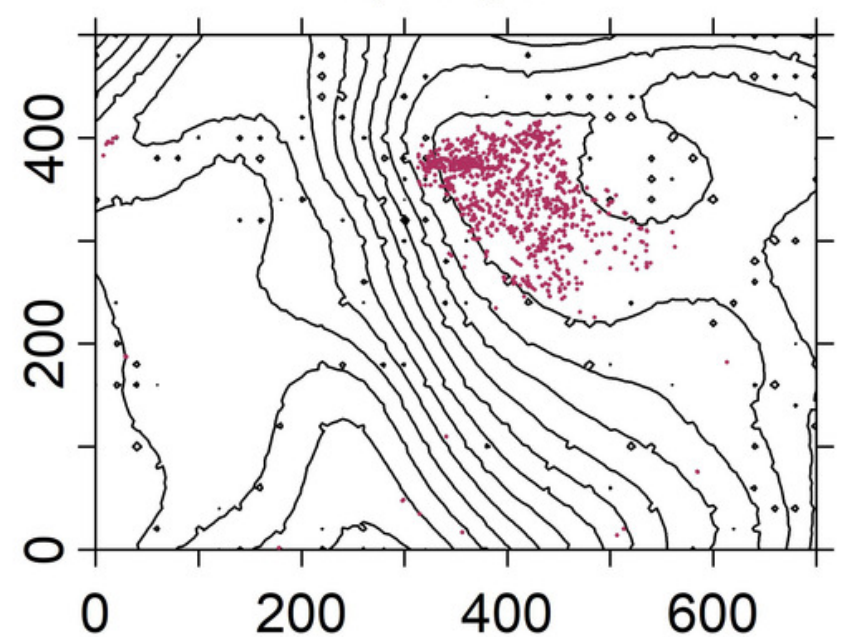

- Kalmia latifolia

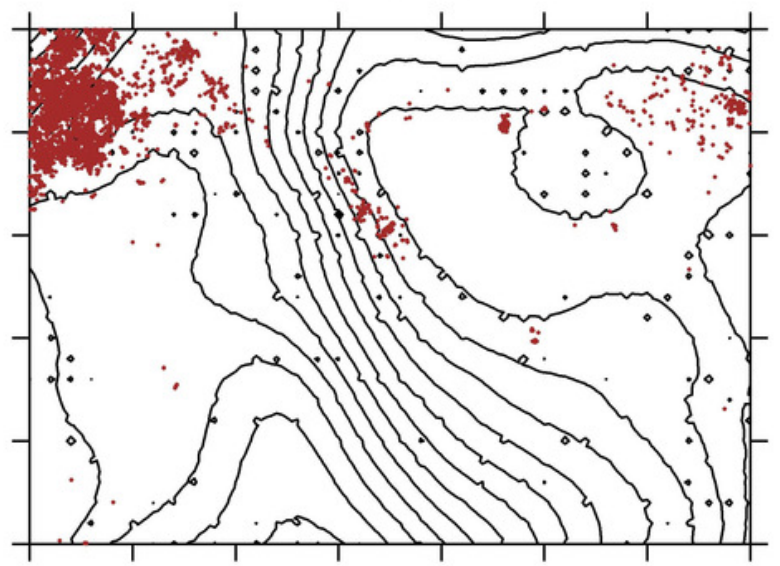

- Hamamelis virginiana

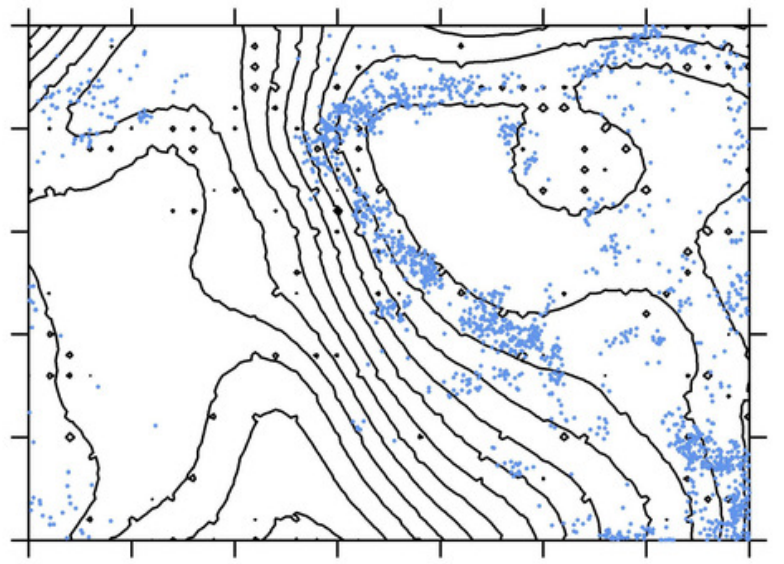

- Viburnum cassinoides

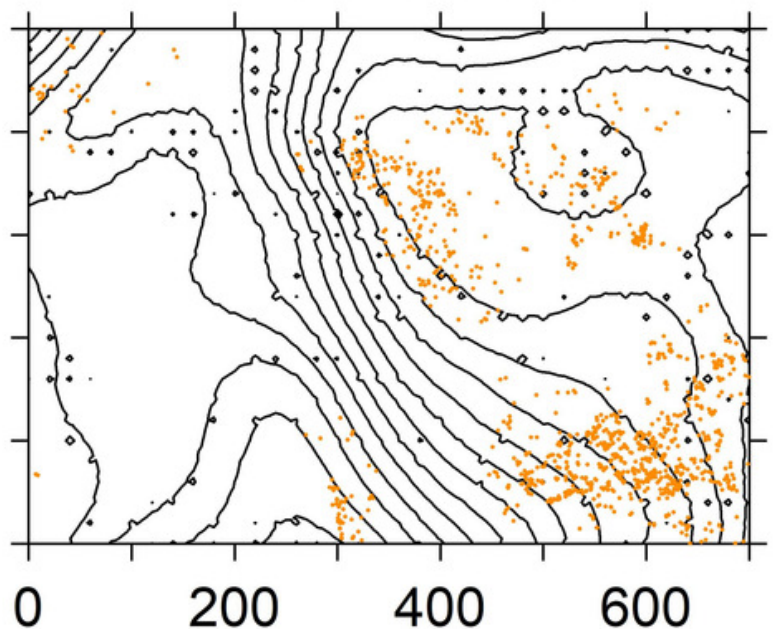




\section{Figure 7}

Observed (blue line) and expected (black dashed line) values of the pair correlation function, $g(r)$, showing the degree of spatial clustering (values $>1$ ) of the seven most dominant tree species in the Harvard Forest plot.

Expected values were obtained from 199 Monte Carlo simulations to completely randomize the spatial position of trees (complete spatial randomness; CSR). 

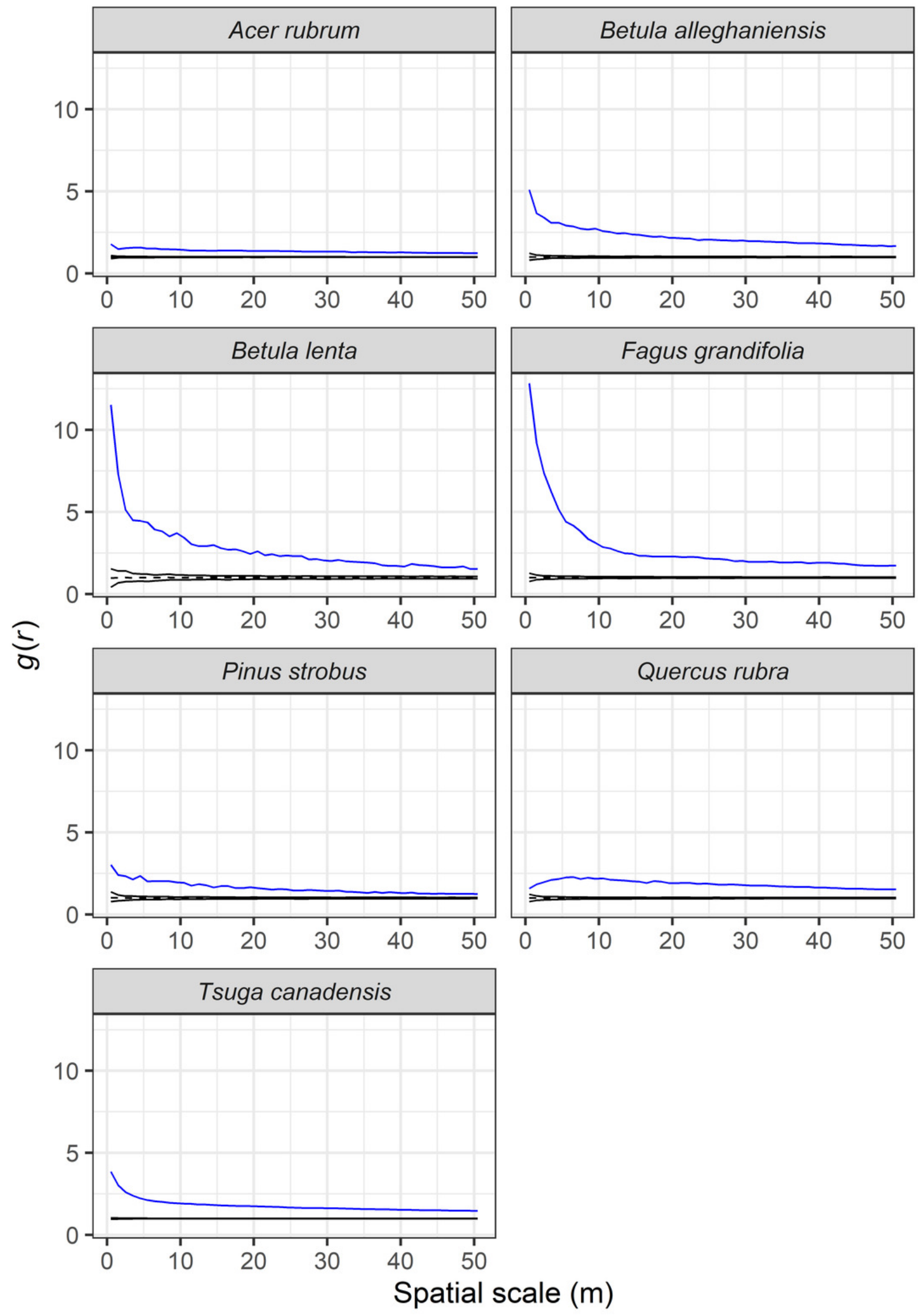


\section{Figure 8}

Univariate mark correlation function analysis results showing the effects of the underlying spatial pattern of trees on the size of conspecific individuals for seven dominant species in the Harvard Forest plot across a range of scales.

The significance of this effect was evaluated by comparing the calculated $\mathrm{kmm}(r)$ against values simulated under a null expectation, where tree sizes were randomly shuffled over all trees for each of the 199 simulations. The blue line indicates calculated $k m m(r)$ values, while the black lines demark the $95 \%$ confidence envelope around simulated $\mathrm{kmm}(r)$ values under the null model. A blue line falling below, within, or above the upper confidence limit, indicates significant negative, independent, or positive correlations among dbh marks for the given species, respectively. 

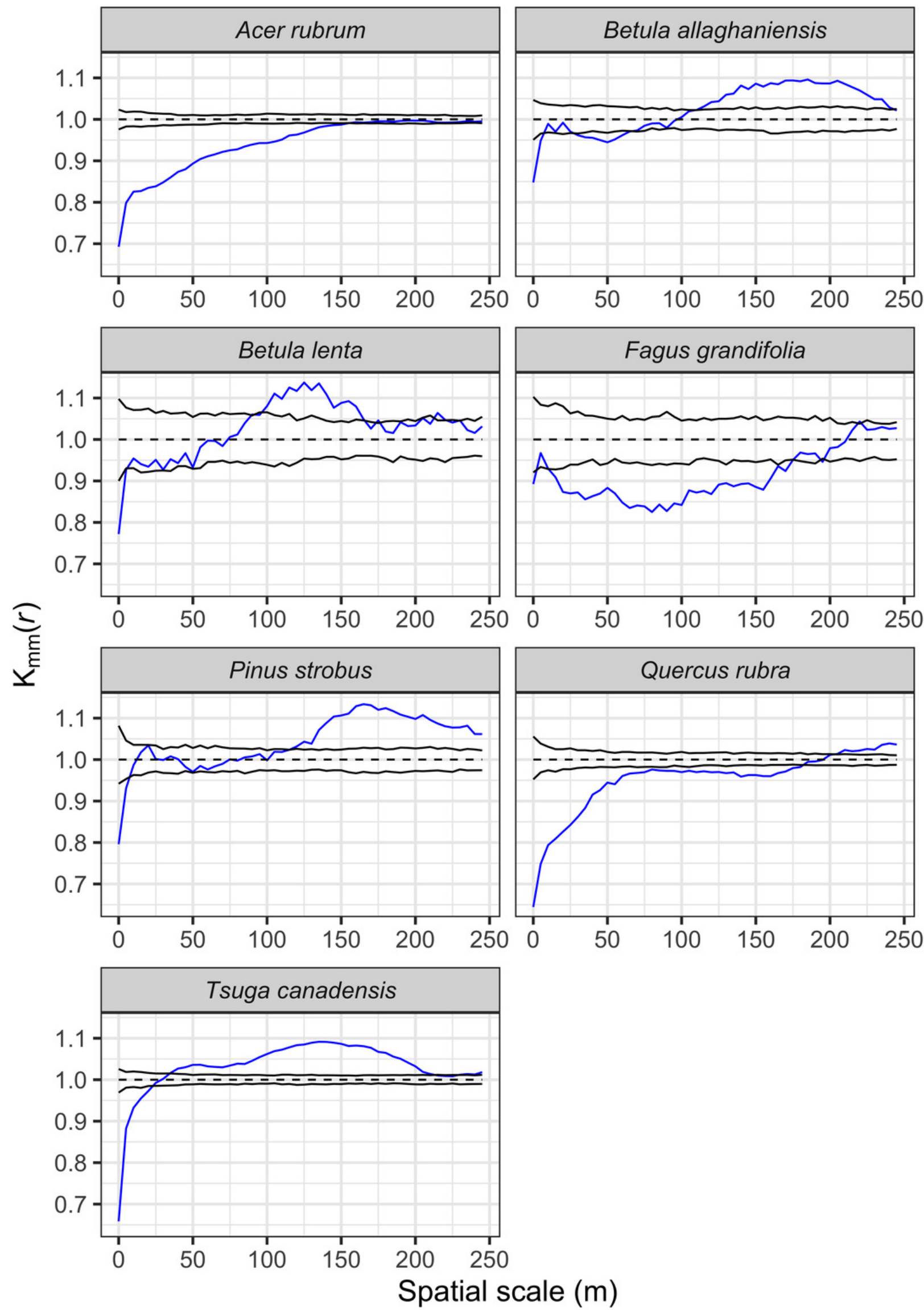


\section{Figure 9}

Bivariate marked point pattern analysis results showing the effects of the size of focal Tsuga canadensis individuals on the size of six other non-focal species in the HF ForestGEO plot across a range of scales.

The significance of this effect was evaluated by comparing the calculated Schlather's I ( $\operatorname{Im} 1 \mathrm{~m} 2(r))$ bivariate correlation statistic against values simulated under a null expectation, where non-focal species' tree sizes were randomly shuffled over trees for each of 199 simulations. The blue line indicates calculated $\operatorname{Im} 1 \mathrm{~m} 2(r)$ values, while the black lines demark the $95 \%$ confidence envelope around simulated $\operatorname{Im} 1 \mathrm{~m} 2(r)$ values under the null model. A blue line falling below, within, or above the upper confidence limit, indicates significant negative, independent, or positive correlations of dbh marks of the given species with the dbh of $T$. canadensis individuals found at a range of distances, respectively. 

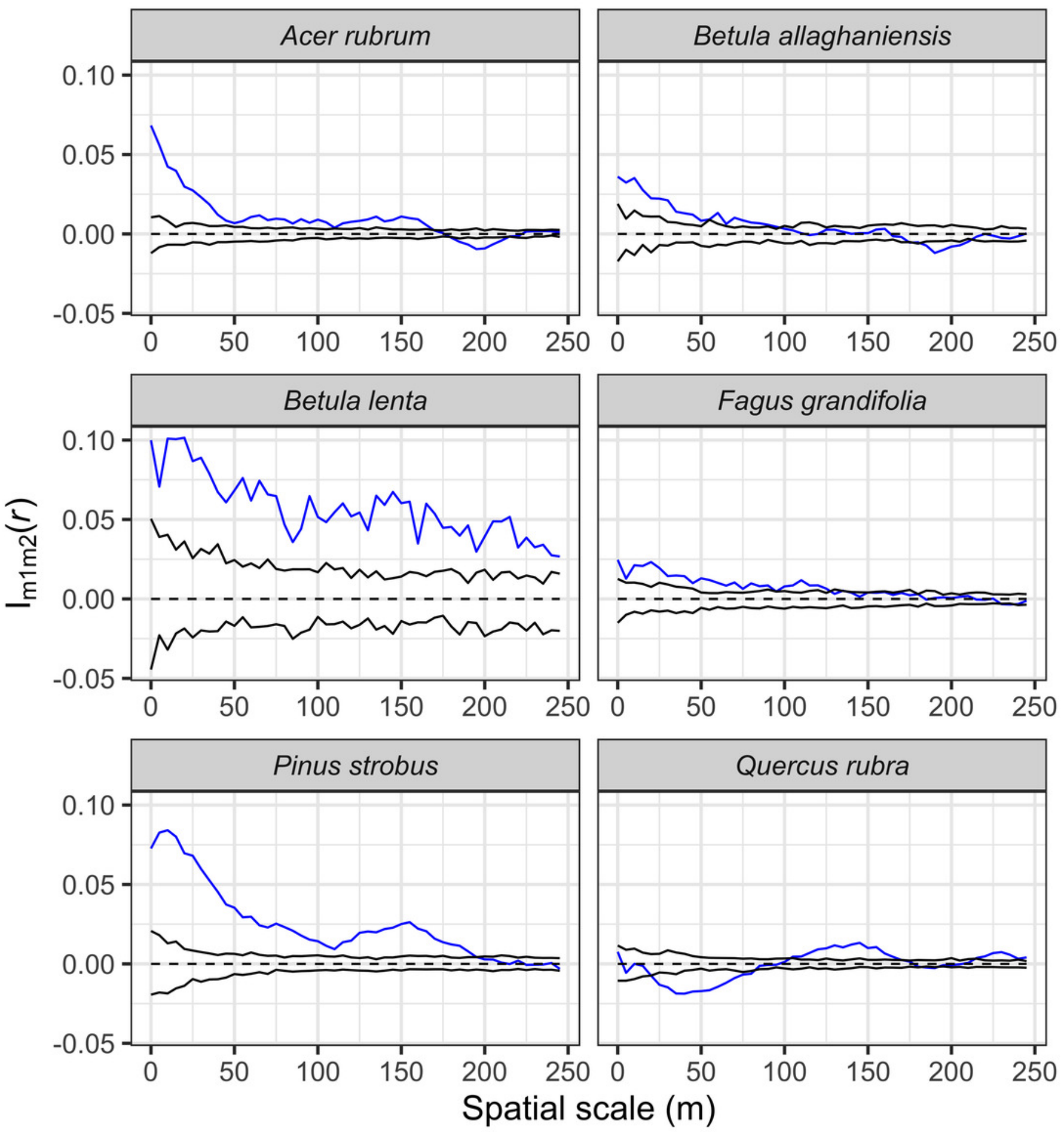


\section{Figure 10}

Variable importance scores, based on the mean decrease in prediction accuracy, from a conditional inference random-forest model predicting tree species abundance values (stems/ha) for the seven most common trees as a function of possible predictors.

Variable importance scores were calculated across 400 random forest iterations and the range of values is from $0-100,000$, reflecting the range of the response variable, abundance. 

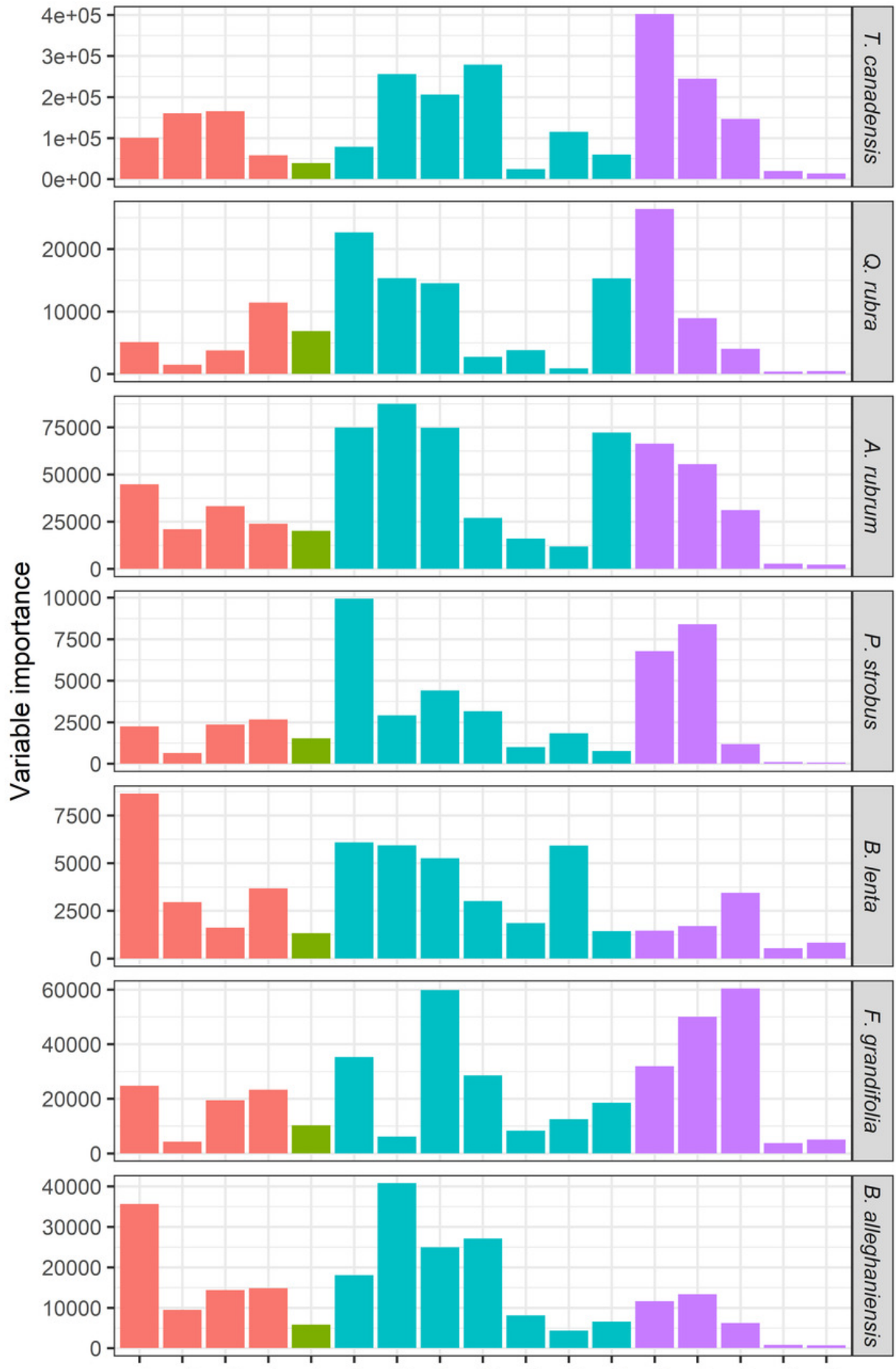

今.

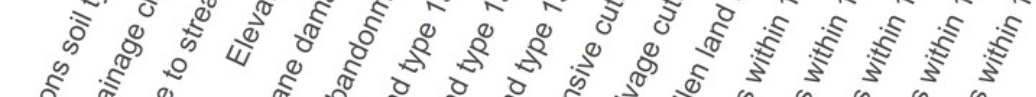

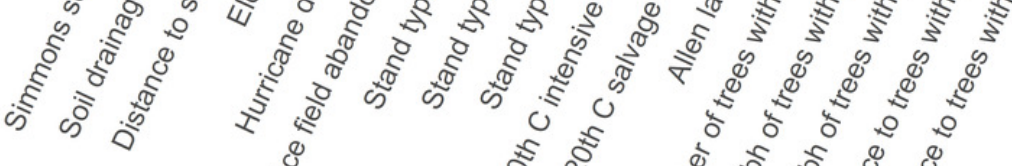

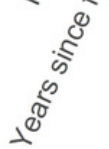

ปิ

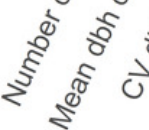

表

\section{Variable category}

Biophysical

Disturbance

Land use history

Stand structure 


\section{Figure 11}

Variable importance scores, based on the mean decrease in prediction accuracy, from a conditional inference random-forest model predicting tree species diameter at breast height (dbh) for the seven most common trees as a function of possible predictors.

Variable importance scores were calculated across 400 random forest iterations and the range of values is from $0-40$, reflecting the range of the response variable, diameter. 

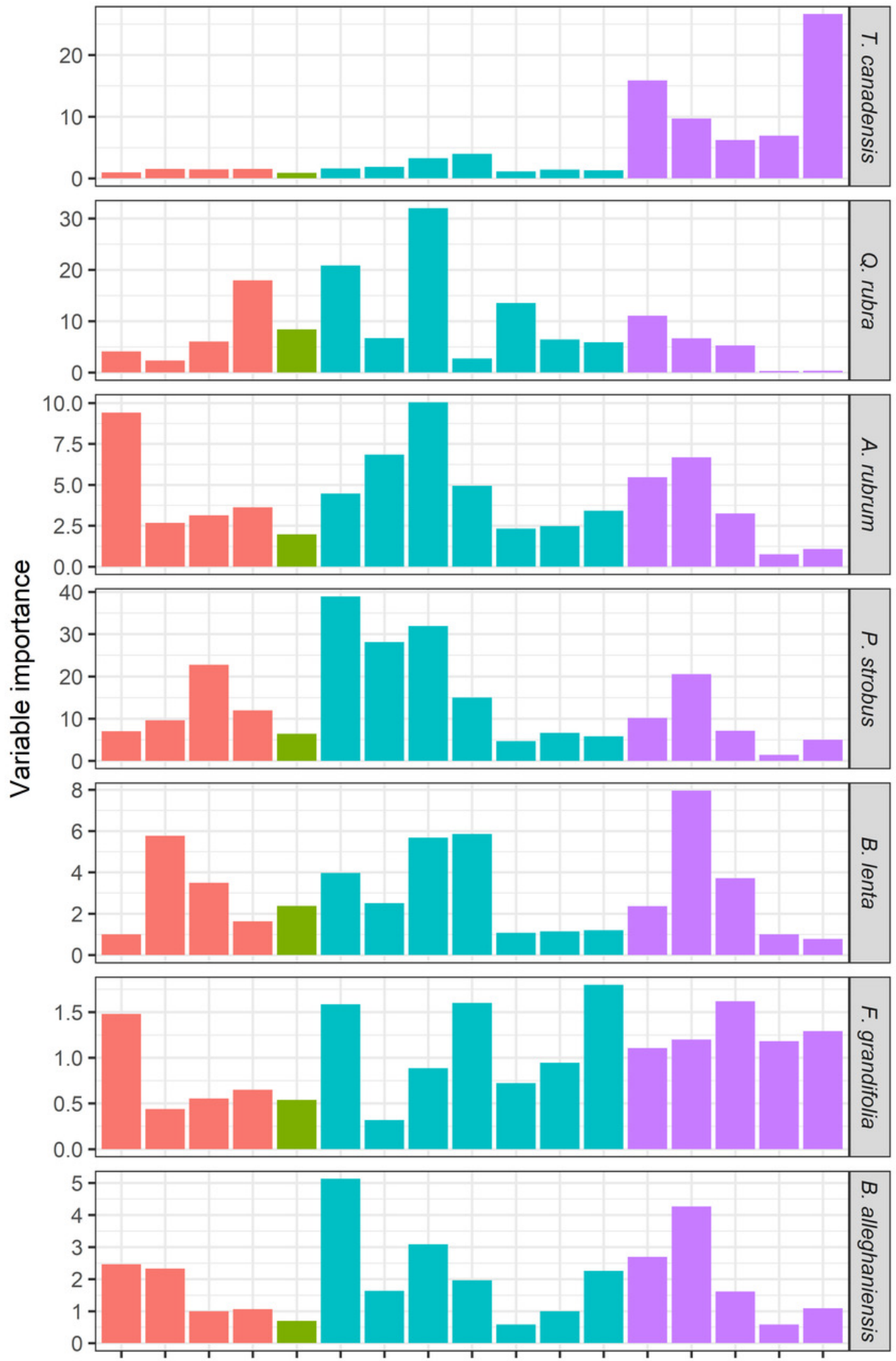

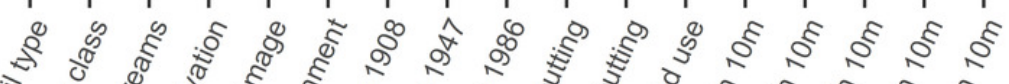

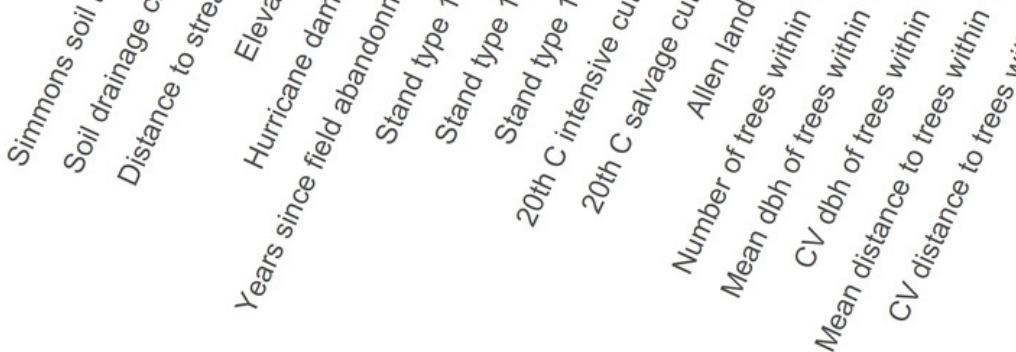

\section{Variable category}

Biophysical

Disturbance

Land use history

Stand structure 


\section{Table $\mathbf{1}$ (on next page)}

Description of land-use history, disturbance, stand, and biophysical predictor variables converted to GIS shapefiles and used to predict current tree species abundance and dbh values across the Harvard Forest ForestGEO plot. 
1 Table 1. Description of land-use history, disturbance, stand, and biophysical predictor variables converted to GIS

2 shapefiles and used to predict current tree species abundance and DBH values across the Harvard Forest ForestGEO 3 plot.

\begin{tabular}{l}
\hline Predictor \\
Land use \\
Stand type $-1908,1947$ \\
Allen Land Use \\
Field Abandonment \\
$20^{\text {th }}$ C. Salvage cutting \\
$20^{\text {th }}$ C. intensive cutting
\end{tabular}

Natural disturbance

Hurricane damage

\section{Stand features}

Mean DBH of trees within $10 \mathrm{~m}$

CV DBH of trees within $10 \mathrm{~m}$

Number of trees within $10 \mathrm{~m}$

Mean distance to trees within $10 \mathrm{~m}$

$\mathrm{CV}$ distance to trees within $10 \mathrm{~m}$

\section{Description}

Early forest stand descriptions in plot recorded by forest type and year

Land-use descriptions derived from degree of soil disturbance, including plow (Ap) horizon presence and depth, recorded by previous HF soil scientist, Arthur Allen.

Years since the date of field abandonment

Areas that experienced cutting following wind damage or other natural disturbance in the early to mid-1900s

Areas that experienced clearcut, shelterwood or reproduction cuts during the early to mid-1900s

Data collected between 1939-1941 on degree of overstory trees uprooted, leaning or broken following 1938 hurricane (Rowlands 1941).

Mean DBH of trees within $10 \mathrm{~m}$ of individual tree stem Coefficient of variation of DBH of trees within $10 \mathrm{~m}$ Number of trees within $10 \mathrm{~m}$ of individual tree stem Mean distance to trees within $10 \mathrm{~m}$ of individual tree stem Coefficient of variation in distance to trees within $10 \mathrm{~m}$ of individual tree stem

\section{Biophysical features}

Elevation

Distance to streams (m)

Soil drainage class

Simmons soil type
Elevation of quadrat as determined from NASA Goddard's Lidar, hyperspectral and thermal (G-LiHT) airborne imager.

Distance from individual tree stem to streams as identified by the National Hydrography Dataset

USDA Natural Resources Conservation Service Soil Survey

Geographic (SSURGO) database soil attribute

Soil Classification from 1:24000 scale surveys Simmons (1941) 


\section{Table 2 (on next page)}

List of total live woody plant density, basal area, and biomass within the 35 ha HF ForestGEO plot in 2014. 
1 Table 2. List of total live woody plant density, basal area, and biomass within the 35 ha HF ForestGEO plot in 2014.

\begin{tabular}{|c|c|c|c|}
\hline Scientific name & $\begin{array}{c}\text { Total live tree } \\
\text { Density } \\
\left(35 \mathrm{ha}^{-1}\right) \\
\end{array}$ & $\begin{array}{l}\text { Total live Basal } \\
\text { area }\left(\mathbf{m}^{2}\right)\end{array}$ & $\begin{array}{c}\text { Total live Biomass } \\
\text { (Mg) }\end{array}$ \\
\hline Acer pensylvanicum & 339 & 0.59 & 1.13 \\
\hline Acer rubrum & 9,723 & 253.54 & 1182.86 \\
\hline Acer saccharum & 1 & $3.12 \mathrm{e}-03$ & 0.02 \\
\hline Alnus incana & 479 & 0.68 & 0.60 \\
\hline Amelanchier laevis & 572 & 0.35 & 0.61 \\
\hline Aronia melanocarpa & 413 & 0.07 & 0.10 \\
\hline Betula alleghaniensis & 4,059 & 36.96 & 207.73 \\
\hline Betula lenta & 1,430 & 21.14 & 124.04 \\
\hline Betula papyrifera & 537 & 14.80 & 72.76 \\
\hline Betula populifolia & 108 & 1.49 & 7.18 \\
\hline Castanea dentata & 732 & 1.12 & 4.35 \\
\hline Crataegus spp. & 180 & 0.14 & 0.27 \\
\hline Fagus grandifolia & 3,802 & 20.93 & 138.58 \\
\hline Frangula alnus & 3 & $7.42 \mathrm{e}-04$ & $4.90 \mathrm{e}-04$ \\
\hline Fraxinus americana & 186 & 3.84 & 23.73 \\
\hline Fraxinus nigra & 34 & 0.17 & 0.82 \\
\hline Hamamelis virginiana & 1,931 & 3.10 & 5.77 \\
\hline Ilex laevigata & 2 & $1.39 \mathrm{e}-03$ & $2.76 \mathrm{e}-03$ \\
\hline
\end{tabular}




\begin{tabular}{|c|c|c|c|}
\hline Ilex mucronata & 598 & 0.64 & 0.58 \\
\hline Ilex verticillata & 9,874 & 3.62 & 6.15 \\
\hline Juniperus communis & 1 & $4.52 \mathrm{e}-04$ & $4.20 \mathrm{e}-04$ \\
\hline Kalmia latifolia & 3,914 & 3.27 & 7.64 \\
\hline Lindera benzoin & 66 & 0.02 & 0.04 \\
\hline Lyonia ligustrina & 1,178 & 0.41 & 2.04 \\
\hline Nyssa sylvatica & 180 & 2.63 & 11.25 \\
\hline Ostrya virginiana & 24 & 0.06 & 0.19 \\
\hline Picea abies & 900 & 24.43 & 93.11 \\
\hline Picea rubens & 101 & 3.61 & 15.15 \\
\hline Pinus resinosa & 790 & 67.23 & 330.28 \\
\hline Pinus strobus & 2,126 & 155.68 & 724.64 \\
\hline Populus grandidentata & 2 & 0.03 & 0.14 \\
\hline Populus tremuloides & 1 & 0.01 & 0.05 \\
\hline Prunus pensylvanica & 11 & 0.05 & 0.98 \\
\hline Prunus serotina & 250 & 5.48 & 34.85 \\
\hline Quercus alba & 38 & 1.89 & 14.53 \\
\hline Quercus rubra & 3,896 & 334.99 & $2,627.07$ \\
\hline Quercus velutina & 206 & 19.28 & 164.46 \\
\hline Rhododendron prinophyllum & 127 & 0.05 & 0.25 \\
\hline Salix spp. & 2 & $1.59 \mathrm{e}-04$ & $1.50 \mathrm{e}-03$ \\
\hline Sambucus racemosa & 2 & $5.65 \mathrm{e}-04$ & $4.03 e-03$ \\
\hline
\end{tabular}




\begin{tabular}{lccc}
\hline Sorbus americana & 66 & 0.26 & 2.78 \\
Toxicodendron radicans & 1 & $1.13 \mathrm{e}-04$ & $1.05 \mathrm{e}-04$ \\
Toxicodendron vernix & 521 & 0.32 & 0.38 \\
Tsuga canadensis & 22,880 & 491.07 & 2138.00 \\
Ulmus americana & 1 & $2.84 \mathrm{e}-04$ & $3.85 \mathrm{e}-04$ \\
Vaccinium corymbosum & 3,531 & 2.39 & 9.58 \\
Viburnum acerifolium & 39 & 0.01 & 0.07 \\
Viburnum dentatum & 325 & 0.08 & 0.52 \\
Viburnum lantanoides & 75 & 0.01 & 0.01 \\
Viburnum nudum & 1,182 & 0.44 & 2.27 \\
\end{tabular}

3 